Review

\title{
Current Techniques and Applications of Mineral Chemistry to Mineral Exploration; Examples from Glaciated Terrain: A Review
}

\author{
Daniel Layton-Matthews ${ }^{1, *}$ and M. Beth McClenaghan ${ }^{2}$
}

check for

updates

Citation: Layton-Matthews, D.;

McClenaghan, M.B. Current

Techniques and Applications of

Mineral Chemistry to Mineral

Exploration; Examples from

Glaciated Terrain: A Review. Minerals

2022, 12, 59. https://doi.org/

$10.3390 / \min 12010059$

Academic Editors: Walid Salama,

Caroline Tiddy and Ryan Noble

Received: 3 December 2021

Accepted: 22 December 2021

Published: 31 December 2021

Publisher's Note: MDPI stays neutral with regard to jurisdictional claims in published maps and institutional affiliations.

Copyright: (c) 2021 by the authors Licensee MDPI, Basel, Switzerland. This article is an open access article distributed under the terms and conditions of the Creative Commons Attribution (CC BY) license (https:// creativecommons.org/licenses/by/ $4.0 /)$.
1 Queen's Facility for Isotope Research, Queen's University, Kingston, ON K7L 3N6, Canada

2 Geological Survey of Canada, 601 Booth Street, Ottawa, ON K1A 0E8, Canada; beth.mcclenaghan@canada.ca

* Correspondence: dlayton@queensu.ca

\begin{abstract}
This paper provides a summary of traditional, current, and developing exploration techniques using indicator minerals derived from glacial sediments, with a focus on Canadian case studies. The 0.25 to $2.0 \mathrm{~mm}$ fraction of heavy mineral concentrates (HMC) from surficial sediments is typically used for indicator mineral surveys, with the finer $(0.25-0.50 \mathrm{~mm})$ fraction used as the default grain size for heavy mineral concentrate studies due to the ease of concentration and separation and subsequent mineralogical identification. Similarly, commonly used indicator minerals (e.g., Kimberlite Indicator Minerals-KIMs) are well known because of ease of optical identification and their ability to survive glacial transport. Herein, we review the last 15 years of the rapidly growing application of Automated Mineralogy (e.g., MLA, QEMSCAN, TIMA, etc) to indicator mineral studies of several ore deposit types, including Ni-Cu-PGE, Volcanogenic Massive Sulfides, and a variety of porphyry systems and glacial sediments down ice of these deposits. These studies have expanded the indicator mineral species that can be applied to mineral exploration and decreased the size of the grains examined down to $\sim 10$ microns. Chemical and isotopic fertility indexes developed for bedrock can now be applied to indicator mineral grains in glacial sediments and these methods will influence the next generation of indicator mineral studies.
\end{abstract}

Keywords: indicator minerals; mineral chemistry; automated mineralogy; MLA; QEMSCAN; laser ablation; mineral exploration; ore deposits

\section{Introduction}

Most new mineral deposits yet to be discovered are likely concealed underneath cover rocks or unconsolidated sediments. The ability to see through this cover and to detect and understand the nature of the underlying bedrock ore environment has become a fundamental aspect of modern mineral exploration and ore deposit science [1-3]. The detection of buried mineral deposits using a variety of surficial materials has been aided using indicator mineral methods, specifically in our ability to (1) identify minerals that are indicative of specific mineral deposit types; (2) identify and separate these same indicator minerals from sediment samples; and (3) measure the unique chemical and isotopic composition of these indicator minerals [4-7].

The extent of the Last Glacial Maximum (LGM) was likely around 34.5 million $\mathrm{km}^{2}$ with the greatest areas impacted in the Northern Hemisphere and covered by the Laurentide and Fennoscandian ice sheets [8]. Over the last 2 million years, most of Canada was glaciated leaving only $10 \%$ of its bedrock surface exposed as outcrop [9]. Approximately $80 \%$ of Canada is covered primarily by glacial and related sediments varying from $<1$ to $300 \mathrm{~m}$ in thickness. Over the past 30 years, indicator mineral methods in Canada have advanced such that they can now be used to detect a broad spectrum of mineral deposit types that are covered by glacial sediments (Table 1). In this paper, we present an overview of the current methods for, and applications of, indicator mineral chemistry with examples 
from the glaciated terrain of Canada, and in particular for till-the optimal indicator mineral sample medium in glaciated terrain [5].

Table 1. Common indicator minerals that can be readily recovered from glacial sediment samples derived from different mineral deposit types (modified from McClenaghan et al., 2020) [10].

\begin{tabular}{|c|c|c|c|}
\hline Deposit Type & $\begin{array}{l}\text { Ore } \\
\text { Elements }\end{array}$ & Common Indicator Minerals & Published Reviews and Selected Examples \\
\hline $\begin{array}{l}\text { Kimberlite-hosted } \\
\text { diamonds }\end{array}$ & $\mathrm{C}$ & $\begin{array}{l}\text { Cr-pyrope, Cr-diopside, eclogitic garnet, } \\
\text { Mg-ilmenite, chromite, olivine, diamond }\end{array}$ & $\begin{array}{l}\text { Lehtonen et al. (2005) [11]; McClenaghan and } \\
\text { Kjarsgaard (2001, 2007) [12,13]; } \\
\text { McClenaghan et al. 2002, 2004, 2012c) [14-16]; } \\
\text { Strand et al. (2009) [17]; Stea et al. (2009) [18]; } \\
\text { Pell et al. (2013) [19] }\end{array}$ \\
\hline $\begin{array}{l}\text { Volcanogenic } \\
\text { massive sulphide }\end{array}$ & $\begin{array}{l}\mathrm{Cu}, \mathrm{Pb}, \mathrm{Zn} \\
\mathrm{Ag}, \mathrm{Au}\end{array}$ & $\begin{array}{c}\text { chalcopyrite, sphalerite, galena, } \\
\text { pyrrhotite, gold, pyrite, gahnite, } \\
\text { staurolite, cassiterite, spessartine, } \\
\text { sillimanite, andalusite, beudantite, } \\
\text { jarosite, barite, tourmaline, hogcomite, } \\
\text { nigerite }\end{array}$ & $\begin{array}{l}\text { Lalonde et al. (1994) [20]; Morris et al. (2002) } \\
\text { [21]; Averill (2001) [22]; Paulen et al., (2013) } \\
\text { [23]; McClenaghan et al. (2015a,b) [24,25]; } \\
\text { Makvandi et al., (2016) [26]; Lougheed et al. } \\
\text { (2020) [27] }\end{array}$ \\
\hline $\begin{array}{l}\text { Carbonate-hosted } \\
\text { lead-zinc }\end{array}$ & $\begin{array}{l}\mathrm{Ag}, \mathrm{Cu}, \mathrm{Pb} \\
\mathrm{Zn}\end{array}$ & $\begin{array}{c}\text { chalcopyrite, sphalerite, galena, pyrite, } \\
\text { barite, spessartine, smithsonite, anglesite, } \\
\text { cerussite }\end{array}$ & $\begin{array}{l}\text { Paulen et al. (2011) [28]; Oviatt et al. (2015) } \\
\text { [29]; McClenaghan et al., (2018) [5] }\end{array}$ \\
\hline Gold & $\mathrm{Au}, \mathrm{Ag}$ & $\begin{array}{l}\text { gold, scheelite, tourmaline, rutile, } \\
\text { sulphides, tellurides, PGM, barite, } \\
\text { cinnabar }\end{array}$ & $\begin{array}{c}\text { Averill and Zimmerman (1986) [30]; Averill } \\
(2001,2013,2017) \text { [22,31,32]; Plouffe (2001) [33]; } \\
\text { McClenaghan (2001) [34]; Sarala et al. ( 2009) } \\
\text { [35]; McClenaghan and Cabri (2011) [36]; } \\
\text { Sarapää and Sarala (2013) [37]; Manéglia et al. } \\
\text { (2018) [38] }\end{array}$ \\
\hline $\begin{array}{l}\text { Magmatic } \\
\text { Ni-Cu-PGE }\end{array}$ & $\mathrm{Ni}, \mathrm{Cu}, \mathrm{PGE}$ & $\begin{array}{l}\text { pentlandite, chalcopyrite, pyrite, } \\
\text { millerite, PGM, chromite, Cr-diopside, } \\
\text { enstatite, olivine, Cr-andradite }\end{array}$ & $\begin{array}{c}\text { Bajc and Hall (2000) [39]; Barnet and Averill } \\
\text { (2010) [40]; McClenaghan and Cabri (2011) [36]; } \\
\text { Averill (2011) [41]; McClenaghan et al. (2013; } \\
\text { 2020b) [42,43]; Hashmi et al. (2021) [44]; } \\
\text { Makvandi et al. (2021) [45] }\end{array}$ \\
\hline Rare metals & Rare Metals & $\begin{array}{l}\text { pyrochlore, columbite, Ta-minerals, } \\
\text { allanite, zircono-silicates, apatite, } \\
\text { monazite, fluorite, rhabdophane, } \\
\text { arfvedsonite }\end{array}$ & $\begin{array}{l}\text { Lehtonen et al. (2015) [46]; Sarapää and Sarala } \\
\text { (2013) [37]; Mao et al. (2016) [47]; Mackay et al. } \\
\text { (2016) [48]; McClenaghan et al. (2019) [49] }\end{array}$ \\
\hline $\begin{array}{l}\text { Porphyry } \\
\text { Cu-Au-Mo }\end{array}$ & $\begin{array}{l}\mathrm{Cu}, \mathrm{Mo}, \mathrm{Au}, \\
\mathrm{Ag}\end{array}$ & $\begin{array}{l}\text { chalocopyrite, chalcocite, pyrite, } \\
\text { molybdenite, gold, silver, epidote, } \\
\text { tourmaline, apatite, andradite, barite, } \\
\text { monazite, rutile, titanite, zircon, jarosite, } \\
\text { malachite, pyrolusite, magnetite }\end{array}$ & $\begin{array}{l}\text { Averill (2011) [41]; Kelley et al. (2011) [50]; } \\
\text { Eppinger et al. (2013) [51]; Hashmi et al. (2015) } \\
\text { [52]; Chapman et al. (2015, 2018) [53,54]; } \\
\text { Plouffe et al. (2016; 2019) [55,56]; Pisiak et al. } \\
\text { (2017) [57]; Plouffe and Ferbey (2017) [58]; } \\
\text { McClenaghan et al. (2020c) [59]; Lee et al., 2021 } \\
\text { [60]; Beckett-Brown et al. (2021) [61] }\end{array}$ \\
\hline $\begin{array}{l}\text { Intrusion-hosted } \\
\text { Sn-W }\end{array}$ & Sn, W, Mo & $\begin{array}{l}\text { cassiterite, scheelite, wolframite, } \\
\text { molybdenite, chalcopyrite, Bi sulphides, } \\
\text { sulphides, fluorite, topaz, tourmaline }\end{array}$ & $\begin{array}{c}\text { McClenaghan et al. (2017a, 2017b) [6,7]; } \\
\text { Poulin et al. (2018) [7], Lougheed et al., } 2021 \\
\text { [62] }\end{array}$ \\
\hline $\begin{array}{l}\text { Iron oxide- } \\
\text { Copper-Gold }\end{array}$ & $\mathrm{Fe}, \mathrm{Cu}, \mathrm{Au}$ & $\begin{array}{c}\text { magnetite, gold, apatite, pyrite, } \\
\text { chalcopyrite, pyrrhotite, titanite, epidote }\end{array}$ & $\begin{array}{l}\text { McMartin et al. (2011) [63]; Sappin et al. (2014) } \\
\text { [64]; Normandeau et al. (2018a, b) [65,66]; }\end{array}$ \\
\hline Uranium & $\mathrm{U}$ & $\begin{array}{l}\text { uraninite }\left({ }^{*} \text { pitchblende), thorianite, }\right. \\
\text { tourmaline, sulphides, monazite, allanite, } \\
\text { zircon, baddelyite, niccolite, U-Th } \\
\text { anatase, U-Th rutile, brannerite, } \\
\text { magnetite }\end{array}$ & $\begin{array}{c}\text { Geddes (1982) [67]; Makvandi et al. }(2017,2019, \\
\text { 2021) [68-70] }\end{array}$ \\
\hline
\end{tabular}




\section{Mineral Identification and Mineral Chemistry}

\subsection{Mineral Identification for $>0.25 \mathrm{~mm}$ (Medium to Very Coarse Sand-Sized) Grains}

The separation and visual identification of indicator minerals from glacial sediment samples relies on characteristics largely related to mineral chemistry, i.e., visual distinctiveness and moderate to high density $[13,22,41]$. Indicator minerals are selected from a $>0.25 \mathrm{~mm}$ heavy mineral concentrate (HMC) after a sediment sample has undergone concentration and separation using various combinations of sizing, density, and magnetic methods (McClenaghan, 2005, 2011) [4,71]. During an optical examination of an HMC under a stereoscopic microscope, indicator minerals are counted and a selection of grains is "picked", a process that may require up to $3 \mathrm{~h}$ per sample. A few grains to several thousand grains may be separated into vials based on colour and mineral habit, such as the well-known kimberlite indicator minerals used for diamond exploration (Figure 1). The production of high-quality HMCs and mineral identification and selection by experienced technicians are vitally important in the first critical step of any indicator mineral chemical study. Selected mineral grains are commonly epoxy-mounted in organized rows (Figure 2A,B), polished, and carbon-coated for examination using microanalytical techniques. Traditional indicator mineral picking of the $>0.25 \mathrm{~mm}$ HMC of till samples for mineral exploration in glaciated terrain has been used for more than 50 years, mostly for the exploration for gold and diamond deposits $[4,12,13,22,43]$.
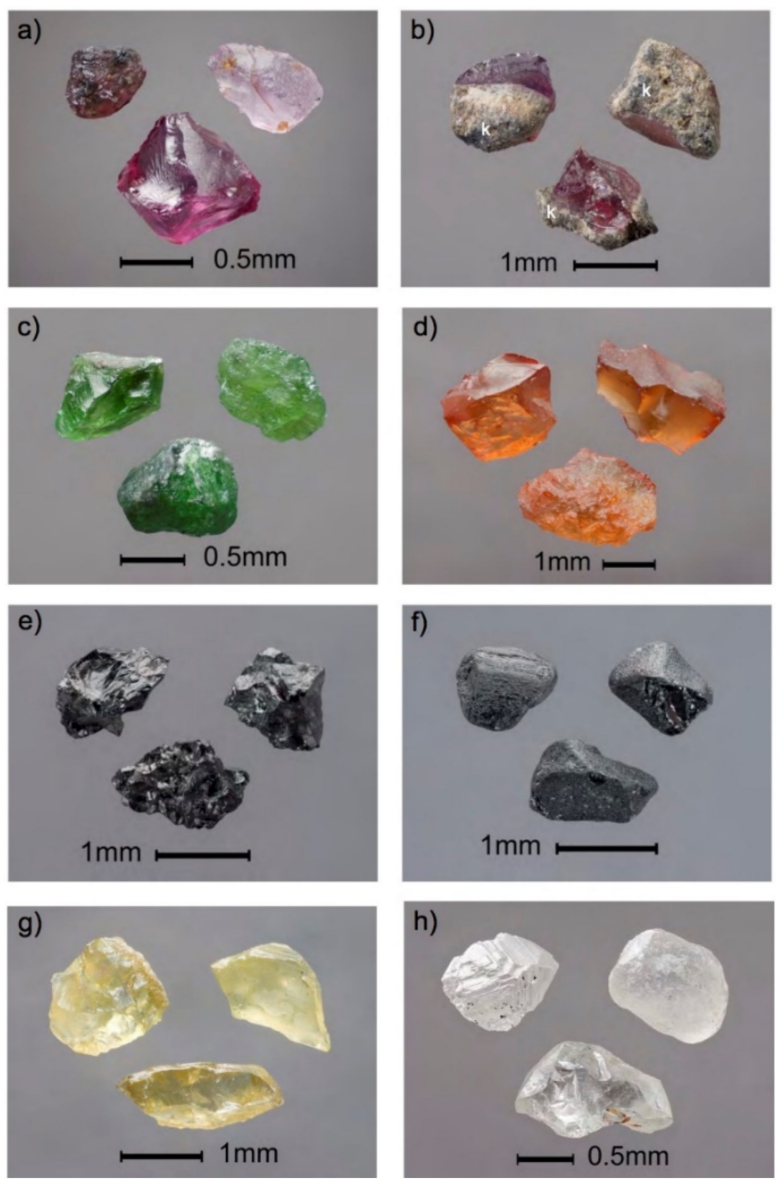

Figure 1. Examples of the colour and habit variations in kimberlite indicator minerals that can be observed using optical techniques (modified from McClenaghan and Paulen, 2020): (a) purple to pink Cr-pyrope; (b) Cr-pyrope with dark green-grey kelyphite rims (k); (c) Cr-diopside; (d) eclogitic garnet; (e) Mg-ilmenite; (f) chromite showing resorbed crystal faces; (g) forsteritic olivine; (h) diamond. Mineral photography by Michael J. Bainbridge. Eclogitic garnet grains provided by Mineral Services; diamond provided by Herb Helmstaedt, Queen's University. Modified from McClenaghan and Paulen (2018) [5]. 

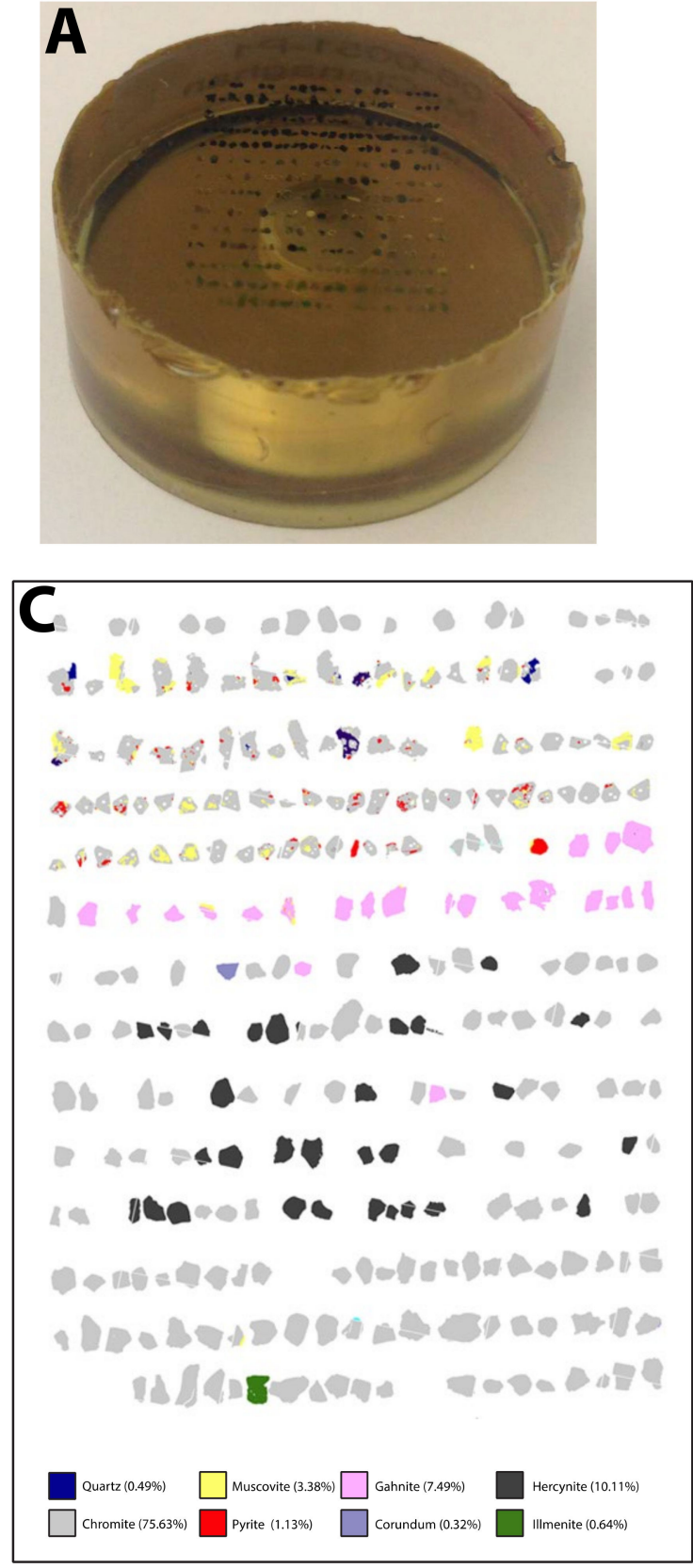
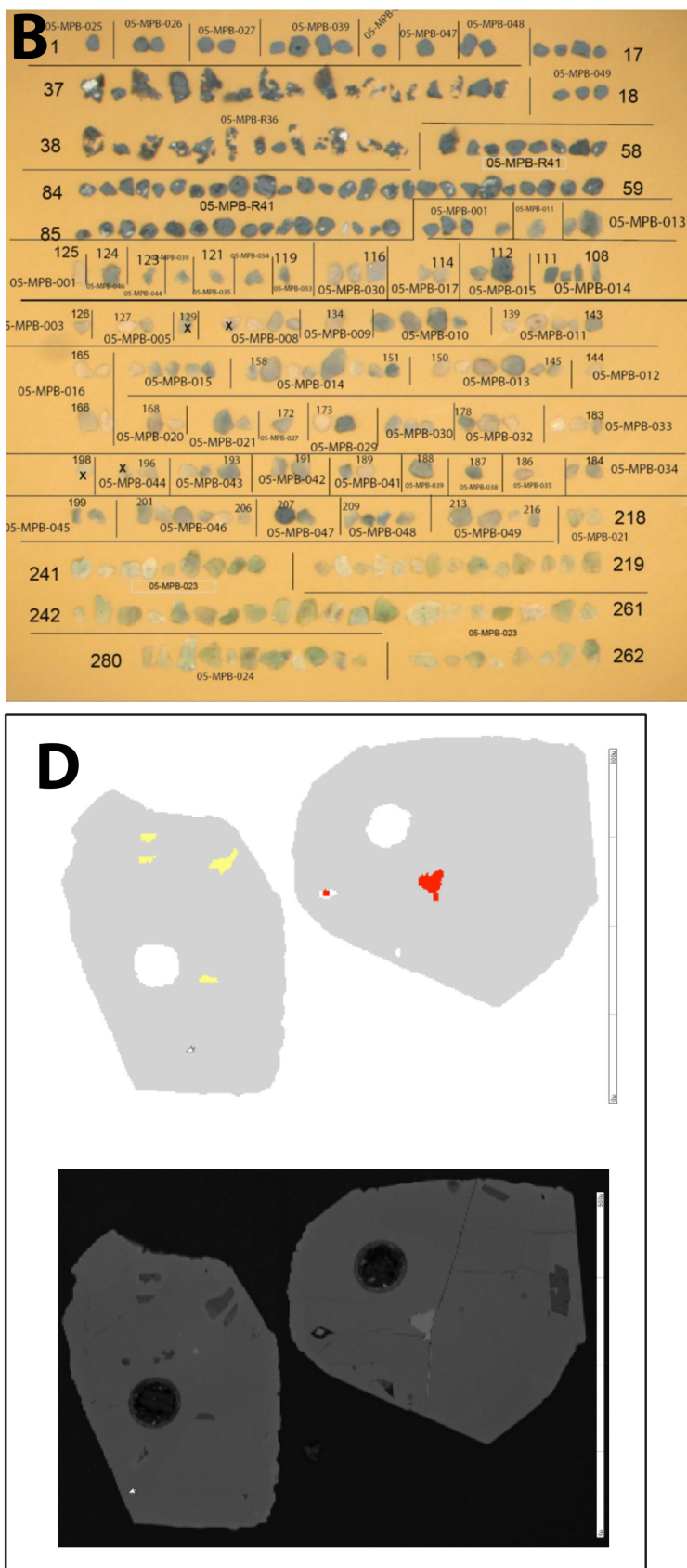

Figure 2. Example of the indicator mineral chemistry workflow from epoxy mount to laser ablation analysis. (A) Epoxy-mounted mineral grains after mineral separation. (B) Optical stereo binocular photomicrograph of polished grains in an epoxy mount; most grains $0.25-0.5 \mathrm{~mm}$ diameter. (C) Falsecolour processed Mineral Liberation Analysis (MLA) image of mineral grains in an epoxy mount. (D) MLA image (upper) of chromite grains (grey) with inclusions (red, yellow) and corresponding backscatter secondary electron image (lower); both imagesf show circular $50 \mu \mathrm{m}$ laser ablations spots in each grain. Scale bar is $500 \mu \mathrm{m}$. Modified from Layton-Matthews et al., 2014 [72].

\subsection{Mineral Identification for $<0.25 \mathrm{~mm}$ (Silt to Fine Sand-Sized) Grains}

The most cost- and time-effective means to identify indicator minerals in a $<0.25 \mathrm{~mm}$ (medium silt and finer) HMC of a sediment sample is using Automated Mineralogy $[27,46,48,73-75]$. The mineral grains in this size range are too small and too numerous to visually sort, identify and count. Instead, Automated Mineralogy methods can be used to identify the minerals $(10,000-100,000)$ in this smaller size fraction. A HMC is produced prior to mineral identification. The $<0.25 \mathrm{~mm}$ fraction of the HMC can be 
further sieved into still smaller size fractions (e.g., 185-250 $\mu \mathrm{m}, 125-250 \mu \mathrm{m}$, or $<64 \mu \mathrm{m}$ ) and then a split $(\sim 0.2-0.4 \mathrm{~g})$ of a specific size fraction is mounted as a monolayer epoxy mount containing 1000s of grains (Figure 3). Better density and representivity of HMC can be achieved through a two-step mounting procedure [27]. Better physical individual grain separation can be facilitated by thoroughly mixing with powdered fine and high purity graphite as a parting agent ( 1:1 graphite to sample by mass) [76-79]. This greatly reduces the digital separation needed in the post-analytical workflow. These mounts are then careful polished, carbon-coated and examined using automated mineralogy methods (see below for further details).
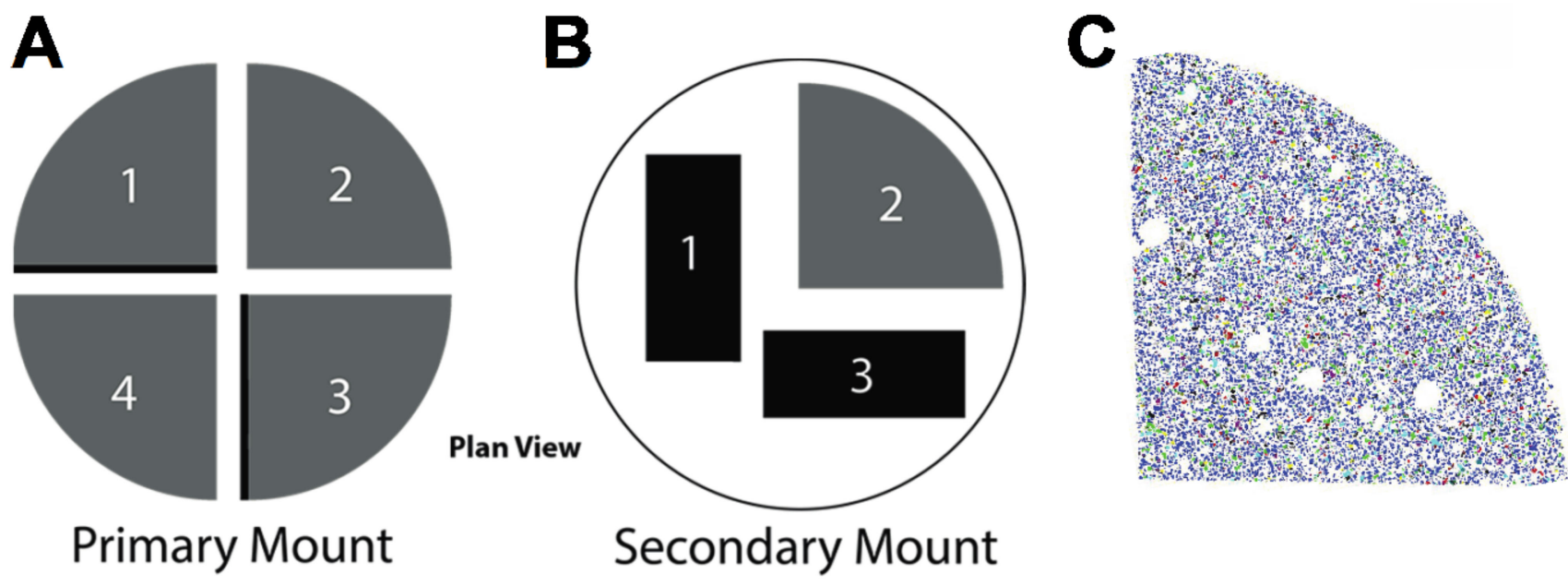

Figure 3. Example of mounting schematic of till in two mounting stages. (A) Primary grain mount was quartered, and three quarters are reoriented and made into (B) second grain mount that was quartered, and three quarters are reoriented and to display one basal surface and two cross-sectional surfaces for analysis. (C) MLA false colour output quarter labelled " 2 " in B. Cross-sectional surfaces are indicated by the black grey bar in A pane of figure. Modified from Lougheed et al., 2020 [27].

\subsubsection{Electron-Based Techniques}

Most mineral chemical investigations examine the indicator mineral mounts using an electron-based instrument. Traditionally, a scanning electron microscope (SEM) is used to examine the spatial distribution of backscatter secondary electrons (BSE), which reflects differences in the average atomic number of an area of a grain. This scanning is done in combination with energy dispersive spectrometry (EDS) to identify relative element concentrations within mineral phases (Figure 4) and mineralogy.

The goals of using an SEM are to (1) confirm of mineralogy that has been determined through visual mineral identification; (2) document mineral associations; (3) document mineral textures and morphology (shape, rounding, size, etc.); and (4) identify optimal mineral grains for further, more costly, mineral chemical characterization. The full characterization of a single epoxy mount with 200 to 500 grains can take 6 to $12 \mathrm{~h}$ on a traditional SEM by an experienced technician. Recent advances in automated scanning electron microscopy coupled with energy-dispersive X-ray spectroscopy (EDS) are transforming the analysis of mineral grain mounts [21,25]. Time-consuming and qualitative mineral descriptions have now been replaced with fast, quantitative, and repeatable SEM analyses. These automated SEM methods provide confirmation of mineralogy, quantification of mineral textures and morphology, and reduces grain mount analysis time to 1 to $2 \mathrm{~h}$. 


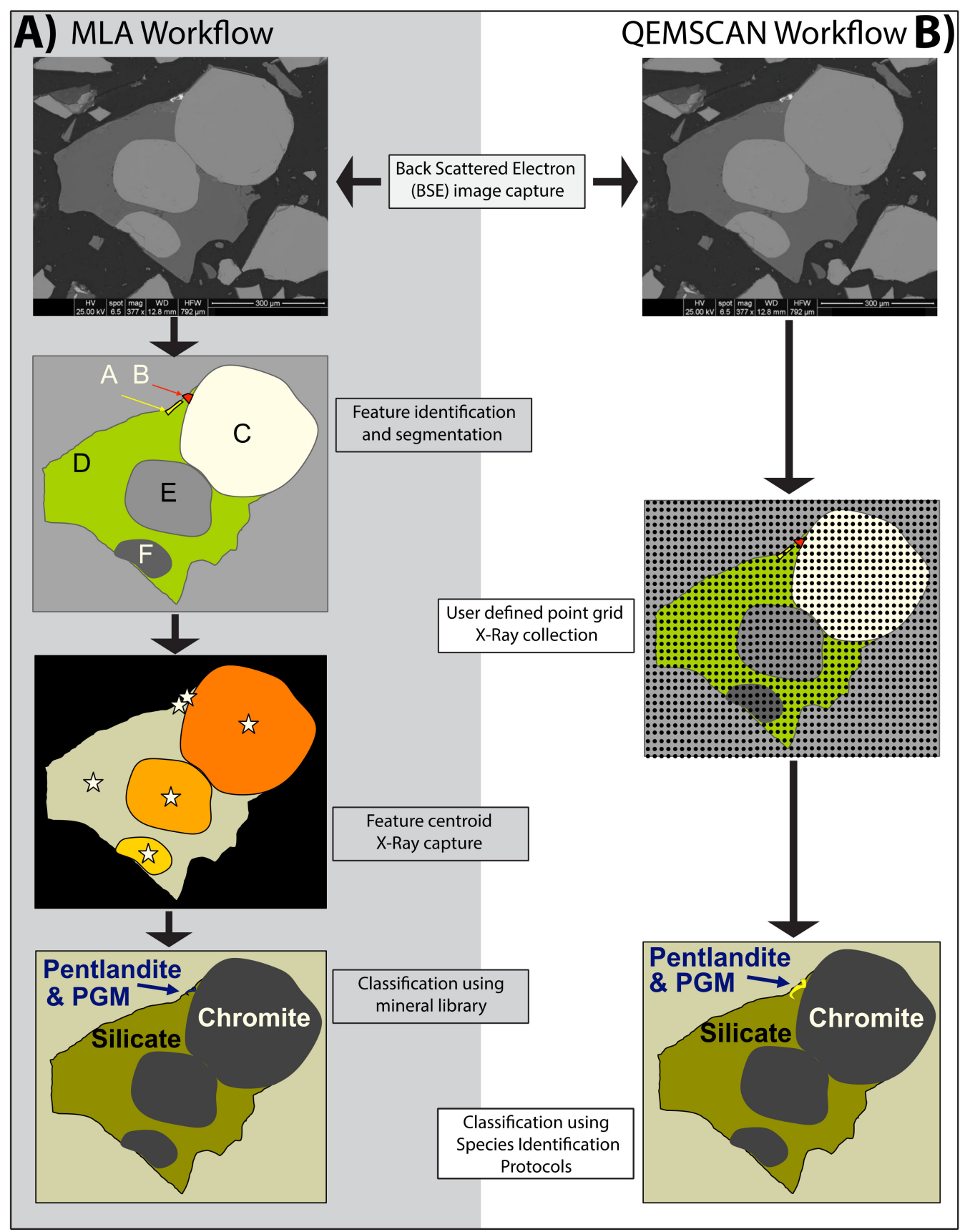

Figure 4. Example of sample workflow for automated mineralogy for (A) mineral liberation analysis (MLA) and (B) QEMSCAN ${ }^{\mathrm{TM}}$. Modified from Layton-Matthews et al., 2014 [72].

The most popular automated SEM supplier was FEI; the company offered tungstenbased or field emission gun-based hardware that can be coupled with either QEM-SCAN ${ }^{\circledR}$ [80] or MLA software [81]. Mineral Liberation Analysis (MLA) was initially developed for the mining industry by the University of Queensland, Australia (JKTech) [82,83]; QEMSCAN ${ }^{\circledR}$ was developed for the mining industry by CSIRO, Australia [80-86]. However, both software packages are currently licensed and sold through Thermo Fisher and are under new software development under the MAPS software package. With the proliferation of the applications of Automated Mineralogy several additional hardware-software platforms have seen application in surficial media characterization, including TESCAN Integrated Mineral Analyzer (TIMA) [87], ZEISS MinSCAN [88] and Oxford Instruments IncaMineral [89].

MLA-automated mineralogy is based on high-resolution BSE images, image analysis, and elemental chemistry from EDS. There are several different MLA data collection modes 
(i.e., XBSE, SPL, XMOD [79,90]), however most rely on the collection of BSE images that are combined to create a mosaic image of an epoxy grain mount or region of interest (Figure 4). An individual grayscale (0-255 range) BSE image is used to remove epoxy from the image using a user defined value $(\sim 10)$, allowing the isolation and centroid image analysis of segmented grains and minerals into individual particles. The MLA software then collects a full X-ray spectrum (EDS) at the centre of each particle (Figure 4) at a user defined dwell time. In post-collection processing, the full X-ray spectrum is compared with a user-defined mineral EDS library and the BSE image to create a coherent data set, which includes a false-colour mineral map (Figure 2C), modal mineralogy, grain size, mineral associations (occurrence and interlocking), particle properties (roundness, area, shape), and mineral liberation.

QEMSCAN $^{\circledR}$-automated mineralogy is fundamentally different from MLA, in that is based on fast mineral identification using point analysis on a finely spaced grid. In most routine analysis, QEMSCAN ${ }^{\circledR}$ collects BSE images to create a mosaic image of an epoxy grain mount; however, during automated measurement, the system collects EDS spectra along a pre-defined grid (similar to modal counting using a petrographic microscope). QEMSCAN $^{\circledR}$ uses the EDS spectra in combination with the BSE image data to determine areas of epoxy and areas of mineral, minimizing the collection of background data. On scanning of mineral phases, a low-count EDS spectrum is collected that allows for ultrafast discrimination of most minerals. QEMSCAN ${ }^{\circledR}$ also differs from MLA in the way that mineralogy is determined. In MLA, minerals are identified through comparison of unknown EDS with a user-defined EDS database of known minerals. In QEMSCAN $^{\circledR}$, a built-in library of 72 elemental reference spectra is used to build a composite elemental spectrum that is then used in conjunction with user-defined Species Identification Protocols (SIP) to identify discrete minerals. In addition to output data similar to MLA, QEMSCAN ${ }^{\circledR}$ produces elemental maps and mineral maps $[80,85,91]$.

MLA- or QEMSCAN ${ }^{\circledR}$-generated BSE and false-colour images of a mounted indicator minerals (Figure 2C) have many advantages over traditional optical microscopy [48,83,90,92]: (1) measurement of compositional data; (2) measurement of thousands of points per sample mount; (3) repeatable and quantitative measurements; (4) fully automated workflow; (5) faster processing time; (6) less mineral identification training required; (7) modal mineralogy calculated assay data; (8) micron-scale resolution; (9) ability to measure and compare grain size; and (10) better determination of analysis points for texturally difficult (i.e., polymineralic) grains and for choosing grains for in situ chemical or isotopic analyses.

The occurrence and modal quantification of distinct heavy minerals in till is of great importance in the definition of glacial dispersal trains in many ore exploration programs (i.e., gold); however, many HMC grain mounts are further characterized for individual mineral chemistry. Many indicator mineral studies in glaciated terrain (e.g., McClenaghan et al. 2002, 2013; Morris et al. 2002; Lehtonen et al. 2005, and references therein) [11,14,21,42] have demonstrated the use of major and minor element mineral chemistry to identify the bedrock provenance and assess fertility.

The quantification of major elements can be obtained quickly for many elements from EDS software using a SEM with detection limits between 2000 and 10,000 ppm $(Z>4)$. However, because EDS requires that individual X-ray spectra be separated from other X-ray spectra in a mineral analysis, some $\mathrm{X}$-ray energies cannot be separated from background radiation (high detection limit) or from X-ray spectra of other elements (i.e., peak overlap). Most modern EDS detectors have an energy resolution of 130 to $160 \mathrm{eV}$ (Full Width Half Max). For example, the quantitative analysis of molybdenite $\left(\mathrm{MoS}_{2}\right)$ by EDS is not easily accomplished because the Mo L alpha line is at $2.2930 \mathrm{keV}$ and overlaps with the S K alpha line at $2.3070 \mathrm{keV}$ [93].

More commonly, indicator minerals are analyzed for major and minor elements using electron probe microanalyzer (EPMA). In principle, an EPMA is very similar to a SEM, as the electron source and focusing column are nearly identical. However, an EPMA and a SEM collect X-ray data differently. Both instruments collect chemical spectra using an 
EDS detector, but on an EPMA, spectra are also collected using wave-length dispersive spectroscopy (WDS). During the collection of WDS, spectra are separated by the mechanical diffraction of X-rays into wavelengths that are individually measured by a detector. Most modern EPMA have up to 5 wavelength dispersive spectrometers that allow the simultaneous measurement of five elements. EDS and WDS each have advantages and disadvantages. EDS can quickly collect a full X-ray spectrum in 10s of seconds; whereas WDS is time consuming, requiring the movement of a diffraction crystal to measure each individual element. Much of the spectral interference encountered during EDS can be eliminated by the high-energy resolution of WDS $(\sim 10 \mathrm{eV})$. The biggest disadvantage of both EDS and WDS systems are the detection limits ( 0.1 and 0.01\%, respectively) for most elements in the characterization of mineral chemistry and the inability of WDS to quantify light elements such as carbon [94,95]. However, the biggest advantage to EPMA is the small sampling volume and spatial resolution, especially with field emission gun instruments [96,97].

\subsubsection{X-ray-Based Techniques}

Mineral characterization and analysis by Micro Energy Dispersive X-ray Fluorescence ( $\mu$-EDXRF) mapping is becoming a routine non-destructive method for the identification of mineralogy and determination of mineral chemistry [98-100]. These benchtop instruments are similar to synchrotron radiation X-ray micro-beam XRF (SR- $\mu$ XRF) [101-103] however, use much lower source energies (e.g., $50 \mathrm{keV}$ vs. >2 GeV) [100,104], are less expensive and are more widely available. Ideally suited for any geological materials, including loose HMC grain mounts, $\mu$-EDXRF gives optimal results on flat, polished mounts because of detrimental topographic shading of the fluorecence [105] on rough surfaces. Advances in capillary optics focus X-rays, producing a small beam $(\sim 5-20 \mu \mathrm{m})[106,107]$ which has allowed the development of high spatial resolution, commercial benchtop $\mu$-EDXRF instruments, such as the M4 Tornado (Bruker Nano GmbH, Germany) [98,108]. As with many of these instruments, beam-size, dwell time and atomic mass can greatly affect the detection limits, however in general for most elements $>10$ ppm limits of detection (LOD) are acheivable in geological media.

The Bruker M4 Tornado $\mu$-EDXRF uses an MLA- and QEMSCAN-like software, the Advanced Mineral Identification and Characterization System (AMICS), and is the latest software package for automated identification and quantification of minerals. The AMICS software [109,110] is divided into 3 parts that include: (1) Investigator, a $\mu$-EDXRF instrument control and data acquisition package; (2) AMICSProcess, a data processing and analysis package and; (3) MineralSTDManager, a mineral database management package [108]. Within the Investigator, several parameters can be set, saved and recalled that include spatial resolution, particle grid (Figure 5A), and dwell time, and assign a mineral database for on-the-fly classification. Post analysis allows AMICSProcess to create an X-ray Intensity mosaic (similar to the BSE mosaic imaging in MLA or QEMSCAN) that reflects the average atomic number $(Z)$ of individual image pixels. The false-coloured Particle Grid (Figure 5A) can be sorted by area within each group (Figure 5B), allowing particles to be grouped by mineralogy, calculated for modal mineralogy ( $\mathrm{w} \%$, Area \%, particle count, etc. Figure 5C) or assay or elemental distribution. Within AMICSProcess sample images can be created to reflect minerals classified (Figure 5D) or can be filtered to highlight and find a specific mineral(s) of interest (Figure 5E). Additionally, AMICSProcess also allows the export of major and trace elemental contents reduced by fundamental parameters [111-114] to be used in data exploration software such as ioGAS (REFLEX, Australia) [115] or through commercial services such as Portable Spectral Services-https: / /www.portaspecs.com/ (accessed on 23 March 2021)(Figure 5F). 

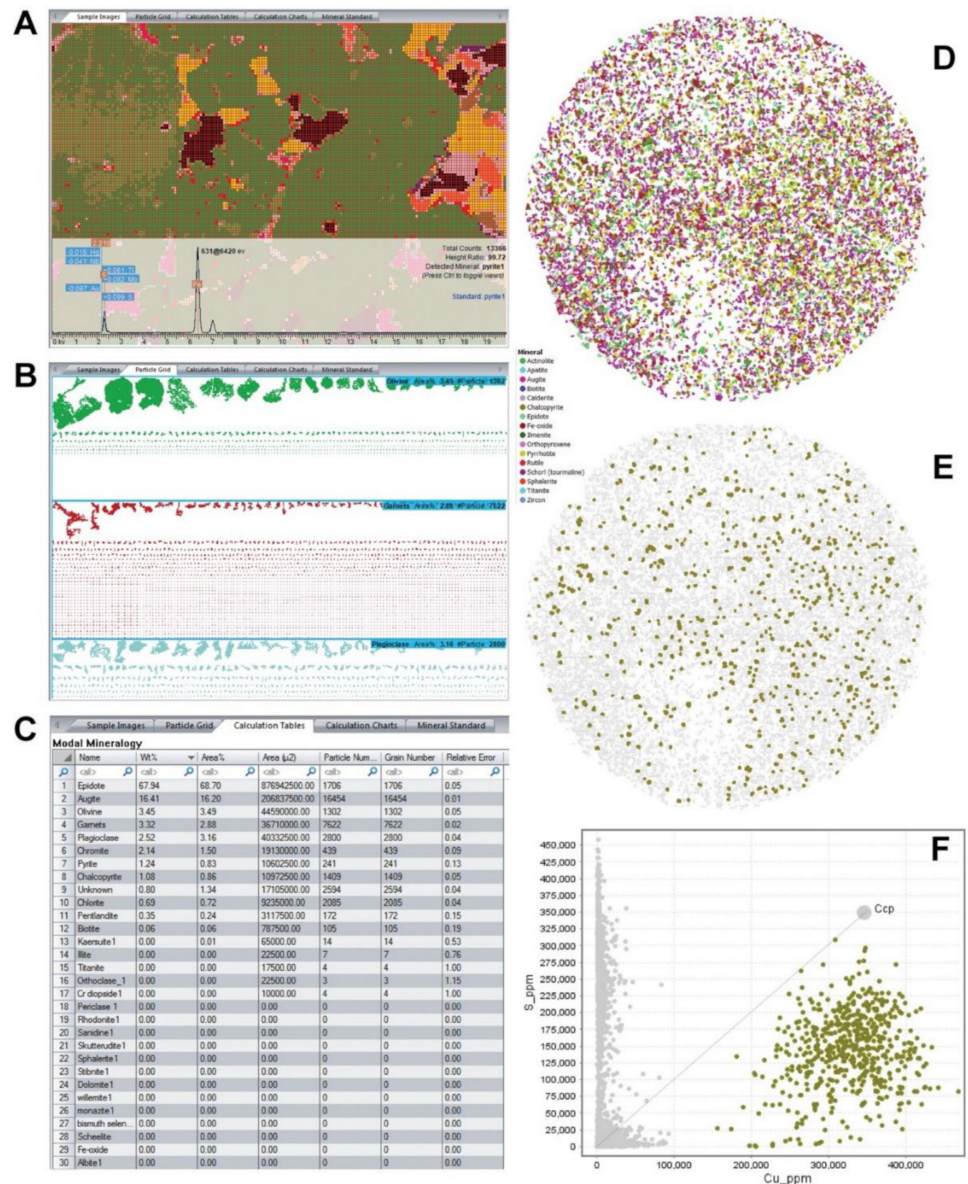

Figure 5. Examples of $\mu$-EDXRF AMICS data exploration. (A) False-coloured sample image classified using the M4 Tornado MineralSTDManager software [108]. (B) Size and mineralogy (olivine, garnet and plagioclase) sorted Particle Grid [58]. (C) Sorted calculation table including wt $\%$, Area\%, and Particle Numbers [108]. (D) False-coloured sample image of $2.5 \mathrm{~cm}$ epoxy mount. (E) False-coloured sample image of $2.5 \mathrm{~cm}$ epoxy mount filtered for chalcopyrite (olive green). (F) Bivariate plot of $\mathrm{S}$ (ppm) vs. $\mathrm{Cu}$ (ppm) filtered by $\mathrm{Cu}>150,000$ ppm in ioGAS ${ }^{\mathrm{TM}}$ [115] to identify chalcopyrite grains of interest. Note images D, E, and F supplied by Portable Spectral Services (PSS) (Pers. Comm., N. Brand 2021).

$\mu$-EDXRF has several distinct advantages over SEM-based methods. Firstly, the average cost of a $\mu$-EDXRF instrument such as the Bruker M4 Tornado is in the order of $\$ 200 \mathrm{k}$ USD, whereas the MLA/QEMSCAN equipped SEM instruments are $>\$ 1$ million USD. Second, quanatative $\mu$-EDXRF can be completed on a variety of media and unlike quantitative MLA/QEMSCAN do not require coating with a conductive layer (i.e., carbon or gold), leaving the material available for repeat or alternate instrument analysis. Thirdly, using similar spatial resolution on identical samples with simple textures (i.e., HMC epoxy mounts), an AMICS $\mu$-EDXRF characterization is faster than that of MLA or QEMSCAN, making instruments such as the Bruker M4 Tornado ideal for quick initial characterization. Fourthly, $\mu$-EDXRF can simultaneously provide mineralogical identification and major and trace element contents. SEM-based methods are limited by EDS requiring the additional use of mass spectrometry-based techniques (see Section 2.2.3) for trace element quantification. One of the main detrimental aspects of $\mu$-EDXRF is spatial resolution. Field emission gun MLA instrumentation are capable of submicron analysis, whereas the capillary optics of $\mu$-EDXRF limit the resolution to $\sim 5 \mu \mathrm{m}$. 


\subsubsection{Mass Spectrometry-Based Techniques}

The use of laser ablation inductively coupled plasma mass spectrometry (LA-ICP-MS) for characterization of mineral chemistry has grown since its first application to geological media [116,117]. Its application for characterizing mineral chemistry has grown in the past 15 years to include a broad range of minerals [118-129].

Conceptually the application of laser ablation for mineral chemical and isotopic analyses is a straightforward, albeit destructive, technique. A short-pulsed (femto- to nanosecond) laser ablates a small volume $\left(5-8000 \mu^{3}\right)$ of a mineral sample over a period of $10 \mathrm{~s}$ of seconds. During ablation the mineral is converted into vapour and aerosol components. This material is then continually transferred in an Ar or He carrier gas to be ionized in an inductively coupled plasma and mass analyzed in either a quadrupole or magnetic-sector mass spectrometer [130].

There are several instrument parameters that must be optimized to measure element and isotopic compositions of a mineral by LA-ICP-MS [131-133]; these include (1) laser pit-size; (2) laser wavelength; (3) laser pulse-rate; (4) mass spectrometer; (5) matrix-match standards; and (6) curve calibration. Most laser ablation instruments are capable of adjusting the laser beam size from 1-2 to 300 microns, however, most analyses are completed at $\sim 30$ microns (Figure 2D). If a laser pit is too small, not enough material is ablated to create a suitable signal in the mass spectrometer. If a laser pit is too large, the mass spectrometer detector may become saturated or go beyond the element calibration curve.

Numerous studies have examined the analyses of geological media using variable laser wavelengths [134-137] and laser pulse-rates [138-142] and collectively using similar laser energies. There is consensus that shorter wavelengths and higher laser pulse rates produce superior data that require fewer corrections for elemental and isotopic bias. In mineral analysis, a shorter wavelength laser (i.e., $193 \mathrm{~nm}$ vs. $213 \mathrm{~nm}$ ) produces a flat-bottomed and sharp-walled ablation pit. The higher pulse rate (i.e., femtosecond vs. nanosecond) of the mineral can produce less thermal heating with a lower abundance of secondary condensates [138,143-145].

Ultimately, the ability of LA-ICP-MS to measure low-concentration elemental and isotopic data is a function of the mass spectrometer paired with the laser ablation system. There are three options for inductively coupled plasma mass spectrometers for use in laser ablation: (1) Quadrupole; (2) Time of Flight; (3) High-resolution single collector; and (4) High-resolution multi-collector.

By far the most common mass spectrometer used in laser ablation studies of mineral chemistry is the quadrupole mass analyzer. These instruments filter ions created in the plasma by mass and charge $(\mathrm{m} / \mathrm{z})$ as they travel to the detector using variable DC voltages on four parallel stainless steel rods. By adjusting the DC voltage on the quadrupoles, the transient ions created in laser ablation can be filtered and analyzed for most elements on the periodic table in milliseconds [130].

Time-of-flight mass spectrometers have seen less application to laser ablation applications in geological sciences. However, they are ideally suited to capitalize on the extremely fast washout times of new ablation cells and higher laser frequencies [146,147]. These plasma-based instruments use the difference in ballistic travel and kinetic energy of light versus heavy isotope masses through a vacuum and a charge potential to separate mass to charge ratios over short time intervals [148]. Current Time-of-flight mass spectrometers can complete a full mass scan at $\sim 30 \mu$ s allowing 33,000 full mass scans per second [96]. Early Time-of-flight mass spectrometers did not have the sensitivity of quadrupole mass analyzers, however recent research would suggest sensitivities that rival sector field instruments and allow single digit parts per million for single-shot laser pulse from a $10-\mu \mathrm{m}$ diameter laser spot [149].

In high-resolution mass spectrometers, ions created in laser ablation and in the inductively coupled plasma are passed along a curved flight path through magnetic and electrical fields to disperse ions according to their momentum and translational energy [150]. By adjusting the magnetic and electro-static fields, the transient ions arriving at the detector(s) 
can be varied on the basis of mass. Because of this geometry, the mass resolution of these instruments is superior to that of quadrupole instruments (e.g., 10,000 versus 600, respectively). As such, fractions of mass unit can be effectively separated during analysis, allowing for separation of polyatomic interferences [130].

For effective ion transmission through both the magnetic and electrical sectors, ions are accelerated at much higher energies than in quadrupole instruments (e.g., $10 \mathrm{kV}$ versus $10 \mathrm{eV}$, respectively). As such, less ion scatter is created, and lower detection limits are observed using high-resolution instruments. For many mineral chemical applications, a high-resolution mass spectrometer commonly has only one detector. However, in applications where isotopic ratios are measured, high-resolution instruments commonly have several detectors (known as multi-collector). These instruments can measure individual isotopes (i.e., ${ }^{204} \mathrm{~Pb},{ }^{206} \mathrm{~Pb},{ }^{207} \mathrm{~Pb},{ }^{208} \mathrm{~Pb}$ ) simultaneously, without adjustment of the magnetic or electric sectors, which yields superior isotopic ratios [151].

Quadrupole and high-resolution mass spectrometers each have advantages and disadvantages in mineral chemical analyses using laser ablation. In quadrupole instruments, a wide range of elements (i.e., $\mathrm{m} / \mathrm{z}$ ) can be analyzed very quickly, compared to magnetic and electrical field sector instruments. In high-resolution instruments, the magnetic sector must be adjusted and allowed to stabilize before analyzing the next mass range [152,153]. Given the transient nature of laser ablation analysis, a quadrupole instrument is much better suited for mineral analyses of samples with varied element mass (i.e., rare earth elements, $\mathrm{U}, \mathrm{Pb})$. When there are narrow mass differences $(<30 \%)$, very small laser ablation pits $(<10 \mu \mathrm{m})$ or isotopic ratios are needed, for which high-resolution mass spectrometers offer vastly superior precision and detection limits [154].

Multi-element trace element analysis by LA-ICP-MS requires the use of suitable reference materials with similar matrix compositions $[155,156]$ and calibration using multiple external standards with a wide-range of elements contents [156-158]. Over the past 10 years there has been a limited effort to find or create matrix-matched standards with variable but homogeneous concentrations of trace elements (i.e., 10, 100, 500 ppm), which is necessary to create standard calibration curves and element quantification. Many of these studies have focused on geological glasses that have been created from rock powder standards [159-163] or by the doping of rock powder standards at variable concentrations $[163,164]$. The use of these standards in conjunction with EPMA data now allows the reliable quantification of many trace elements in minerals using LA-ICP-MS.

\section{Indicator Mineral Examples in Glaciated Terrain}

Examples of the application of automated mineralogy, EPMA and LA-ICP-MS to characterize indicator minerals used to explore for mineral deposits in the recently (Pleistocene) glaciated terrain of Canada are described below.

\subsection{Volcanogenic Massive Sulphide Deposits}

To assist exploration for volcanogenic massive sulphide (VMS) deposits in northern Canada, an indicator mineral survey was completed around the Archean Izok Lake $\mathrm{Zn}-\mathrm{Cu}-\mathrm{Pb}$ Ag volcanogenic massive sulphide (VMS) deposit (Figure 5) in Nunavut, Canada $[24,165,166]$. During the mid to Late Wisconsinan, southwest ice flow followed by west- to west-northwesttrending ice flow eroded indicator minerals from the mineralized bedrock and transported and deposited them down ice as till [23].

Mineralized bedrock samples as well as till samples were collected up- and down-ice of the Izok Lake deposit (Figure 5) and processed to recover HMCs $\left(>3.2 \mathrm{~g} / \mathrm{cm}^{3}\right)$ from which the $0.25-0.5,0.5-1.0$, and $1.0-2.0 \mathrm{~mm}$ non-ferromagnetic heavy mineral fractions were examined using optical techniques [165]. Grain mounts for indicator minerals recovered from bedrock samples were examined first using MLA-ESEM to quantify modal mineralogy, mineral associations (Figure 6), grain shape, and grain size to determine the minerals that could be expected in till samples. EPMA was completed on a selection of indicator minerals to confirm visual identification and to characterize trace element compositions. 
Indicator minerals identified in mineralized bedrock and till down ice of the deposit include: chalcopyrite, galena, sphalerite, chalcopyrite, and gahnite (Zn-spinel) (Figure 7). The distribution of gahnite in till reflects both phases of ice flow, forming a wide glacial dispersal fan down ice of the deposit (Figure 8). EPMA data were used to identify the compositional range (Mg-rich vs. Fe-rich) of gahnite (Figure 9), showing that most grains in till are Fe-rich and that the rarer Mg-rich grains were sourced from the central zone of the deposit.

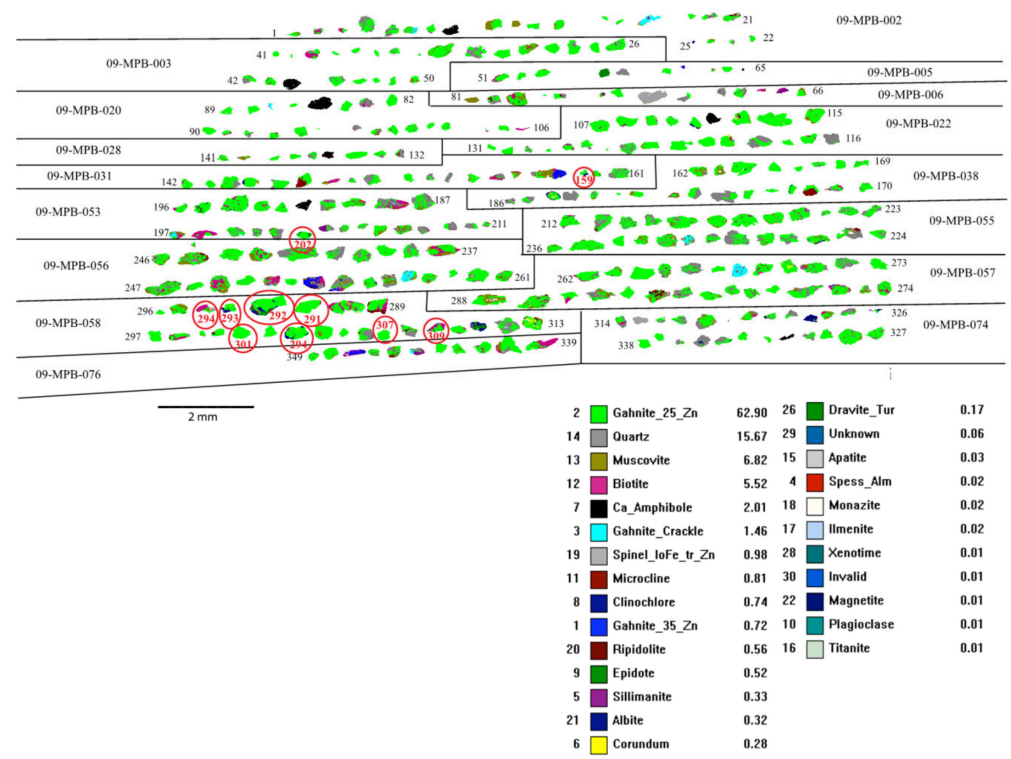

Figure 6. MLA-SEM image of gahnite grain mount 10-0269-P01 for Izok Lake samples. Adhering gangue mineral compositions are indicated with various colours outlined in the legend. Till sample numbers are listed on the outer sides of the image and grain position numbers on the mount are listed at the end of each row. Red circles indicate those grains for which the LA-ICP-MS/EPMA mineral chemistry is anomalous (Hicken, 2012 [165]).
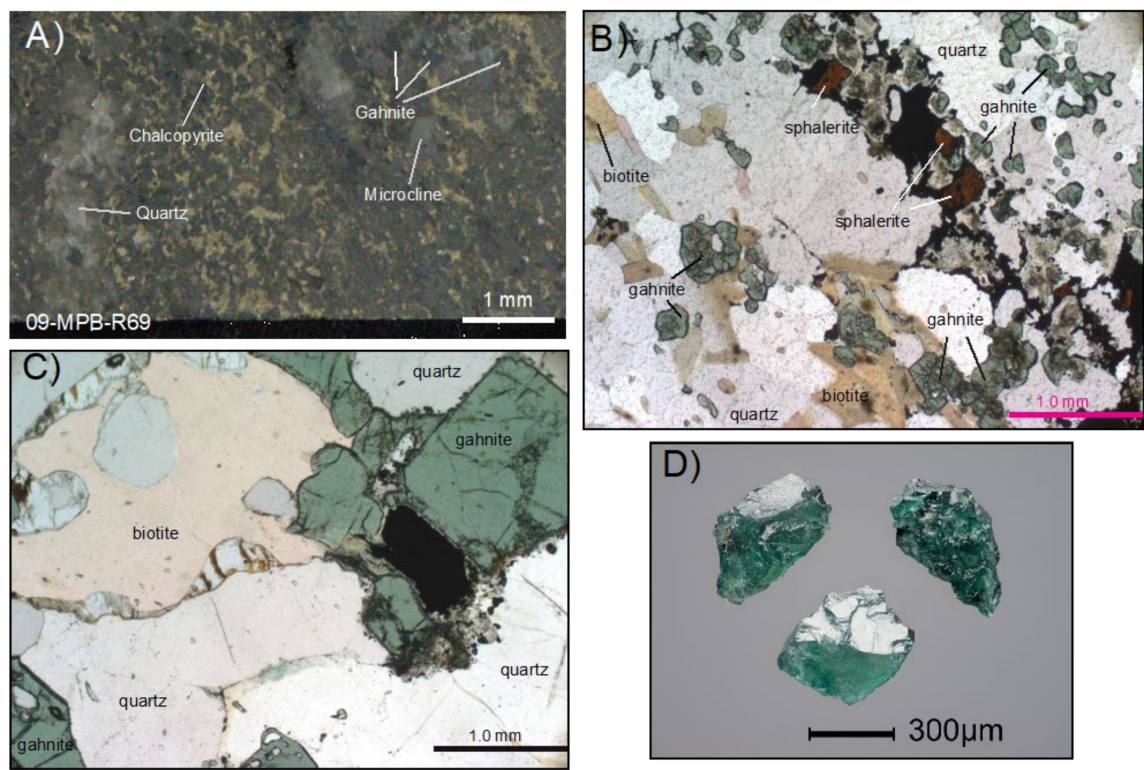

Figure 7. Gahnite grains in bedrock and till samples from Izok Lake: (A) polished slab of drill core (sample 09-MPB-R69); (B,C) polished thin sections (sample 09-MPB-R37 and 09-MPB-R41B, respectively); (D) grains from heavy mineral concentrate of till sample 12-MPB-913 (photograph by M.J. Bainbridge Photography). Modified from Hicken (2012) [165]. 


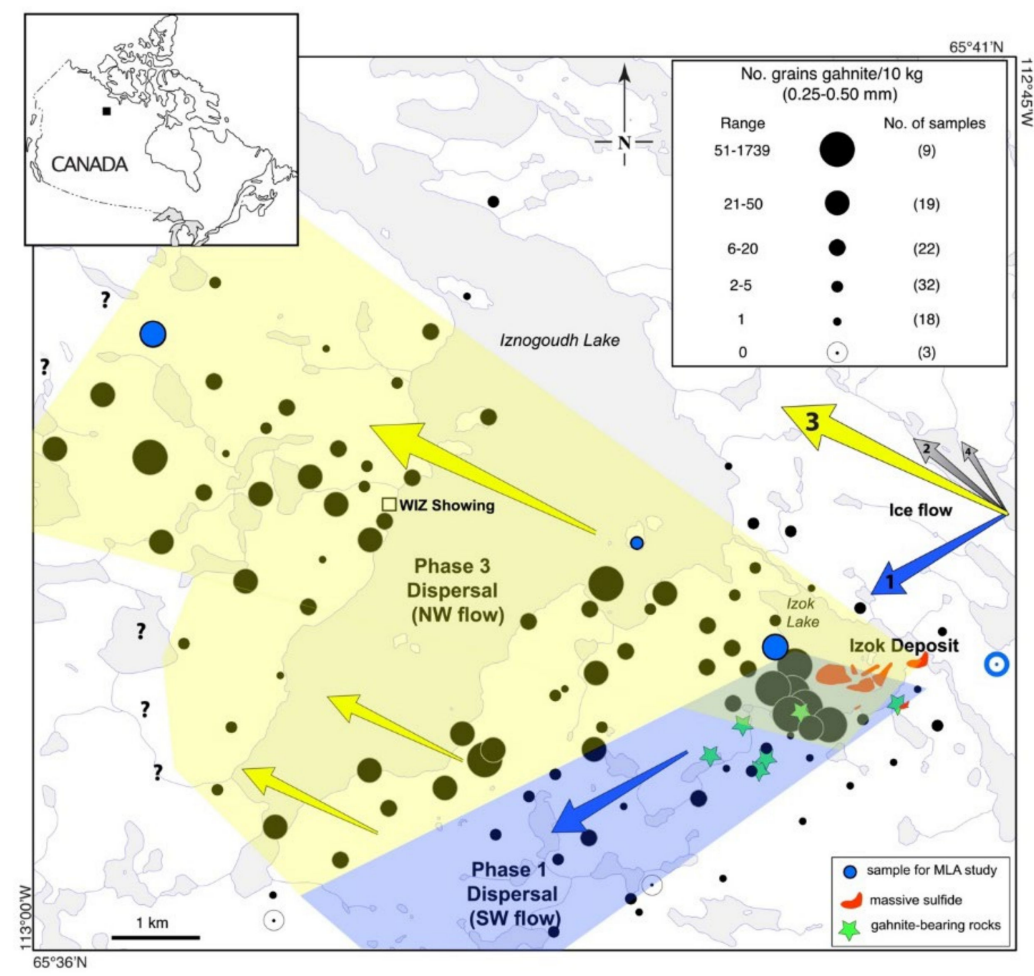

Figure 8. Fan-shaped glacial dispersal of gahnite abundance in the $0.25-0.5 \mathrm{~mm}$ fraction of till (normalized to a $10 \mathrm{~kg}$ ) down-ice of the Izok Lake volcanogenic massive sulphide deposit in northern Canada. The fan formed by two phases of ice flow towards the southwest (blue polygon) and northwest (yellow polygon). Arrows indicate relative ice-flow chronology $(1=$ oldest) and vigor (arrow size) of flow events. Blue dots indicate the four till samples for which the $<0.25 \mathrm{~mm}$ heavy mineral fraction was examined using MLA. Modified from McClenaghan et al. (2015 [24]). Location of mineralization indicated by solid red polygons and additional gahnite-bearing rocks by green stars.

The gahnite found in till at Izok Lake was found to contain elevated contents of transition metals $(\mathrm{Co}>\mathrm{Ti}>\mathrm{Ni}>\mathrm{Mo}>\mathrm{Cr}>\mathrm{Cu}>\mathrm{Pb})$ through LA-ICP-MS. Given the age of the Izok Lake deposit ( 2.7 Ga) $[167,168]$ and the possible younger granitic or Helikianaged Mackenzie Swarm provenance for the gahnite, LA-ICP-MS in Pb contained in the gahnite was completed. The $\mathrm{Pb} / \mathrm{Pb}$ dating of individual grains allowed the interpretation of gahnite sourcing from metamorphic footwall stringer sulphide zone from the Izok Lake deposit (Figure 10).

The $<0.25 \mathrm{~mm}$ HMC of 4 till samples ranging from $1 \mathrm{~km}$ up-ice to $9 \mathrm{~km}$ down-ice of the deposit (Figure 8) was examined using MLA-ESEM to compare abundances and mineral associations to the coarser $(>0.25 \mathrm{~mm})$ optically counted indicator minerals. MLA of the finer HMC fraction indicates that the same indicator minerals occur in the $<0.25 \mathrm{~mm}$ and that these smaller grains can be detected much farther down ice (Lougheed et al., 2020), thus expanding the areal extent of the glacial dispersal fan, and hence the exploration target. For example, sulphide minerals in the coarse $(>0.25 \mathrm{~mm}) \mathrm{HMC}$ are detectable up to $2 \mathrm{~km}$ down ice of the deposit and up to $8 \mathrm{~km}$ down ice in the fine grained $(<0.25 \mathrm{~mm}) \mathrm{HMC}$ (Figure 11). 

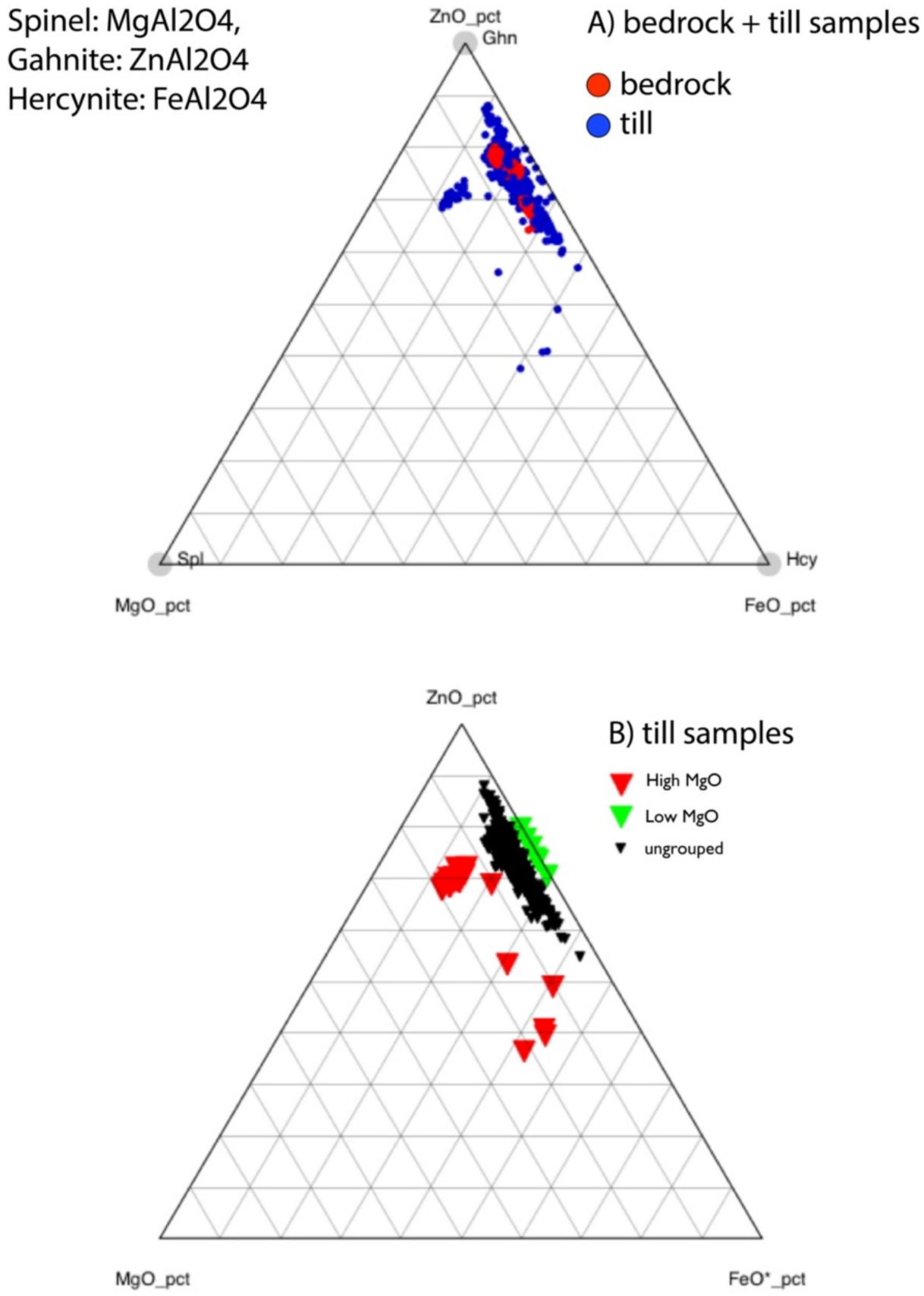

Figure 9. Ternary plot of zincian spinel compositional in terms of gahnite, spinel and hercynite end members for: (A) bedrock from Izok Lake deposit, and (B) till samples down ice of the Izok Lake deposit. 

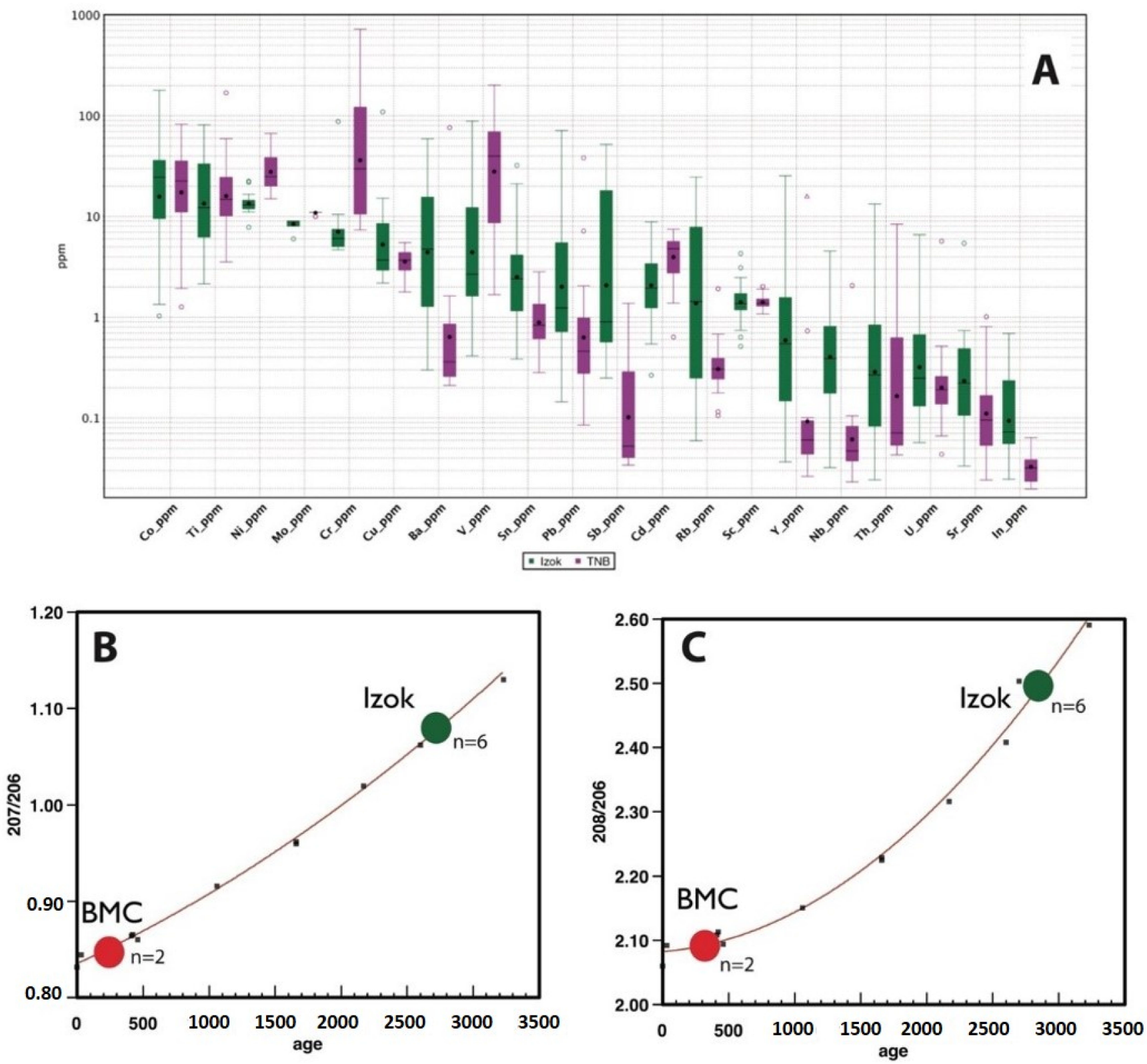

Figure 10. (A) Box and Whisker plot of LA-ICP-MS quadrupole trace element data for gahnite from tills from the Izok Lake VMS and the Thompson Ni-Cu PGE deposits areas. (B) LA-ICP-MS ${ }^{207} \mathrm{~Pb} /{ }^{206} \mathrm{~Pb}$ age relations for Izok Lake VMS (green circles) and Halfmile Lake VMS (Bathurst Mining Camp, New Brunswick: red circles). (C) LA-ICP-MS ${ }^{208} \mathrm{~Pb} /{ }^{206} \mathrm{~Pb}$ age relations for Izok Lake VMS (green circles) and Halfmile Lake VMS (Bathurst Mining Camp, New Brunswick: red circles). Red lines are an approximation of terrestrial lead isotopic evolution (Stacey and Kramers 1975) [169]. High-precision U/Pb ages for Halfmile Lake is $465 \mathrm{Ma}$ (van Staal et al. 2003) [170], for is Izok Lake is $2623 \pm 20$ Ma (Mortensen et al. 1988) [168] and 2680.5 +7/-3 Ma (J. Gebert, unpub. 1995). 

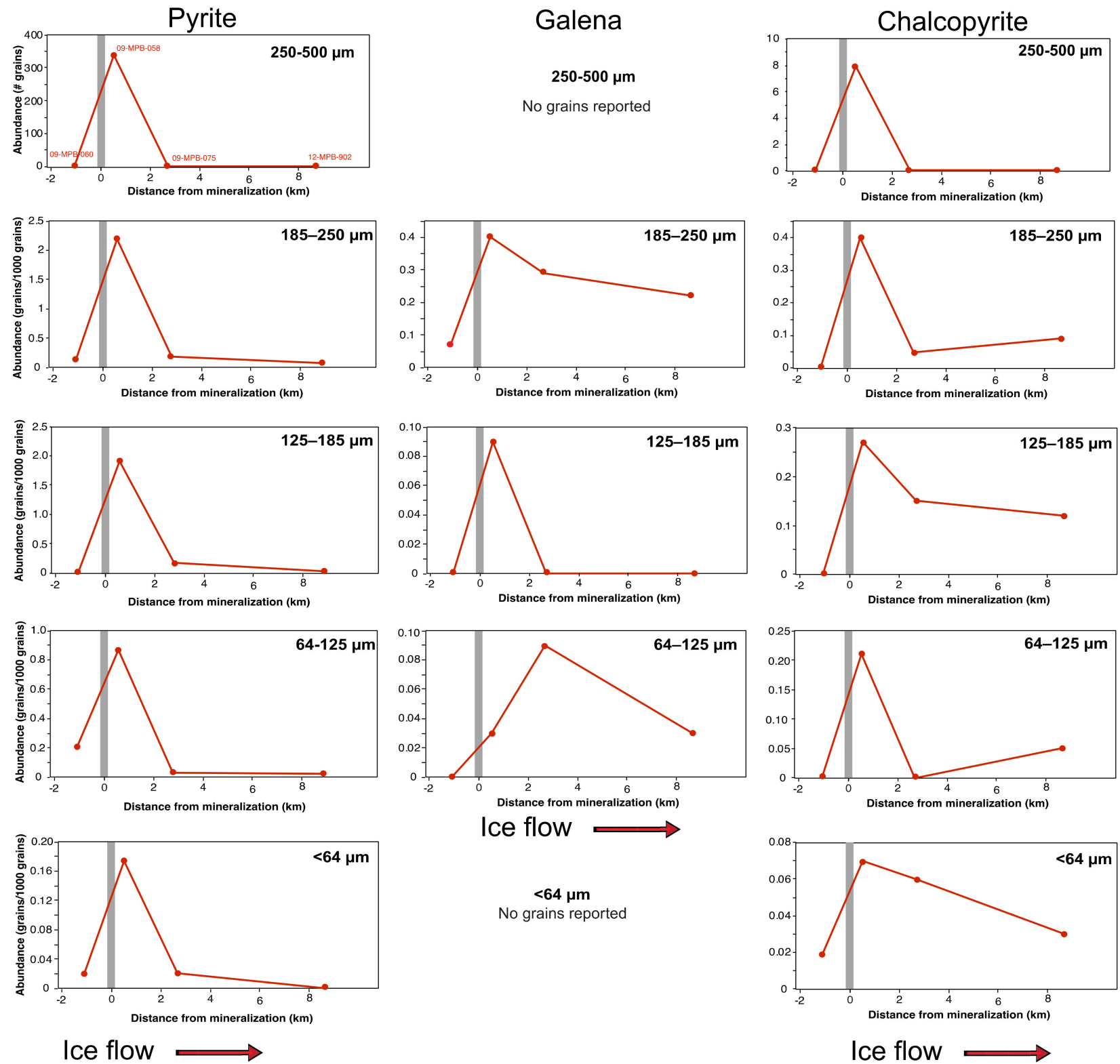

Ice flow

Figure 11. Lines plots comparing the abundance of pyrite, galena, and chalcopyrite grains in 5 different size fractions of heavy mineral concentrates (HMC) from till samples up and down ice of the Izok Lake VMS deposit. Location of mineralization is indicated by grey vertical line in each plot. Uppermost plots $(250-500 \mu \mathrm{m})$ represent grain abundance $/ 10 \mathrm{~kg}$ determined by visual inspection of the HMC. Lower 4 plots ( $<250 \mu \mathrm{m}$ fractions) represent grains abundance/1000 grains determined by MLA. Modified from Lougheed et al. (2020) [27].

\subsection{Magmatic Ni-Cu Deposits}

Sulphide, oxide and silicate indicator minerals have been recovered from till down ice of known magmatic Ni-Cu-PGE deposits. These minerals include pentlandite, pyrrhotite, chalcopyrite, pyrite, gold, platinum group minerals (PGM), chromite, Cr-diopside, and $\mathrm{Cr}$-andradite [39-43]. However, few studies of magmatic Ni-Cu indicator minerals in glacial sediments have included the use of mineral chemistry. One exception to this is the McClenaghan et al. [42] application EPMA techniques to chromite in mineralized and barren bedrock samples to document the mineralization signature (elevated $\mathrm{ZnO}$ ) for the Proterozoic Thompson Nickel Belt Ni-Cu deposits (Figure 12-colored symbols). They identified similar mineralization signatures in chromite in till down ice (west and southwest) of the Thompson deposits (Figure 12-black symbols). LA-ICP-MS of chromite further 
confirmed the elevated $\mathrm{ZnO}$ content and also identified $\mathrm{V}$ as an additional discriminator to identify the Thompson Ni-Cu ore signatures in spinels [171].

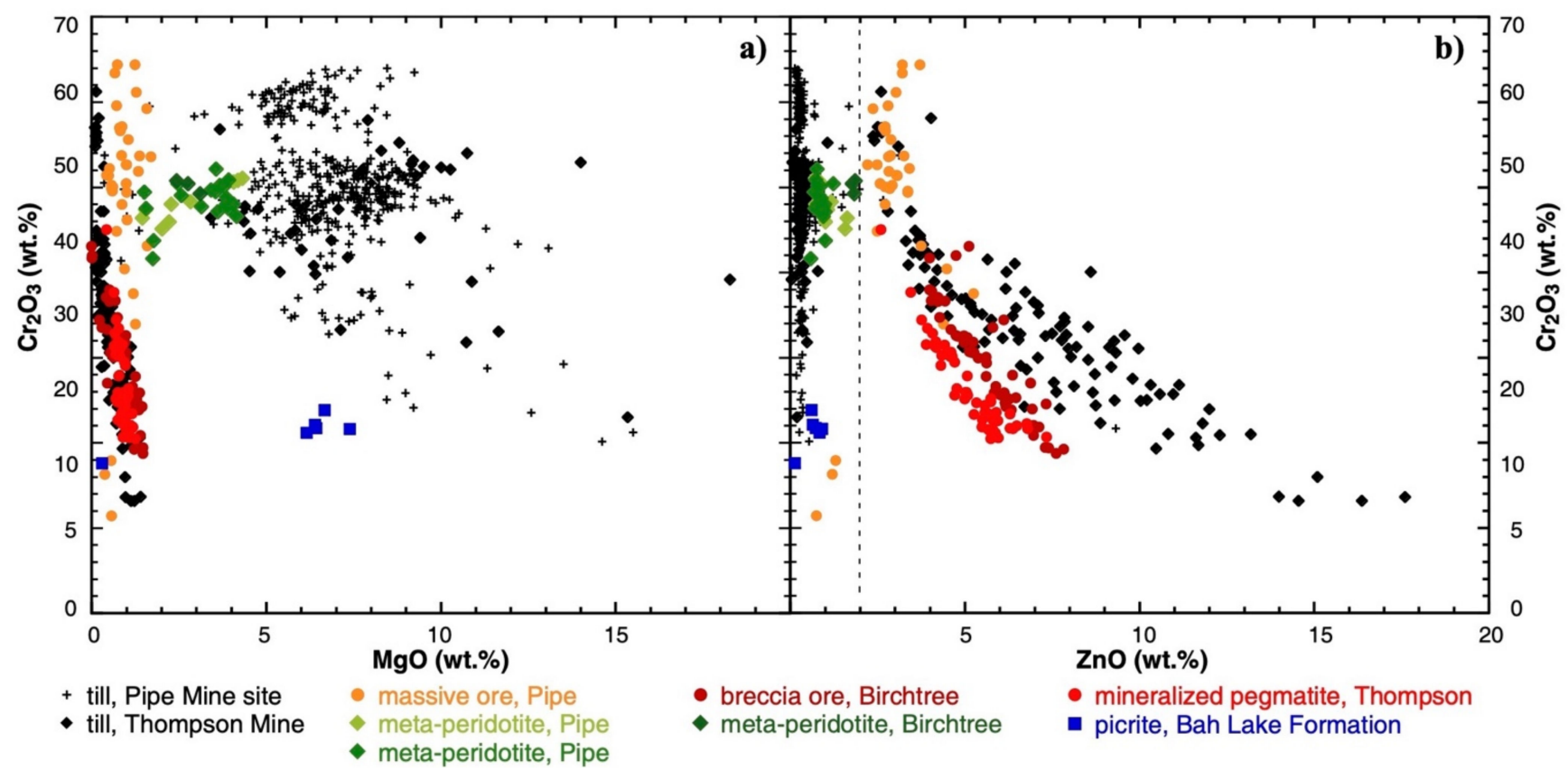

Figure 12. (a) $\mathrm{Cr}_{2} \mathrm{O}_{3}$ versus $\mathrm{MgO}$ and (b) $\mathrm{Cr}_{2} \mathrm{O}_{3}$ versus $\mathrm{ZnO}$ concentrations in chromian spinels from bedrock and till samples from the Thompson Ni Belt: mineralized bedrock (orange and red symbols), unmineralized bedrock (blue and green symbols), and till samples (black symbols). Dashed vertical line indicates $2 \mathrm{wt} \% \mathrm{ZnO}$. Modified from McClenaghan et al. (2013) [42].

The occurrence of the highest metamorphic grade in the belt (at Thompson Mine-South Pit) [172-174] coupled with the highest $\mathrm{ZnO}$ and $\mathrm{Al}_{2} \mathrm{O}_{3}$ contents of spinel group minerals that trend toward the gahnite-hercynite tie line imply a metamorphic/metasomatic origin for these spinels. The correlation of the highest $\mathrm{ZnO}$ within spinel group minerals and the highest concentration of sulfide mineralization in the Thompson Nickel Belt implies that this unique spinel group mineral chemistry is indicative of a mineralized ore system at upper amphibolite facies. This study showed that the distinctive mineralization signature in chromite in the belt can be used to further explore the heavy-drift covered region using indicator methods.

\subsection{Porphyry Cu Deposits}

Common indicator minerals of porphyry $\mathrm{Cu}$ deposits that can be readily recovered from glacial sediments include chalcopyrite, pyrite, gold, epidote, tourmaline, jarosite, apatite titanite, and andradite $[41,50,58,175,176]$. Some case studies around porphyry $\mathrm{Cu}$ deposits in the glaciated terrain of western Canada have used EPMA and LA-ICP-MS methods to establish deposit signatures from bedrock samples and identified the same signature in till samples down ice, providing insights into glacial dispersal patterns and demonstrating that mineral chemistry can be used to identify the presence of mineralized bedrock in a region.

One example of the use of mineral chemistry is the study of tourmaline in till down ice of the Woodjam porphyry $\mathrm{Cu}-\mathrm{Au}$ deposit [177] in western Canada. The distribution of tourmaline in till (Figure 13A) indicates that it is likely an indicator of the mineralization, but the broad tourmaline distribution pattern, including in samples up ice of mineralization, suggest that some tourmaline grains in till may also be derived from unmineralized bedrock. Using a combination of EPMA and LA-ICP-MS chemical (oxy-dravite povondraite trend, high $\mathrm{Sr}$, low $\mathrm{Zn}$ and $\mathrm{Pb}$ ) and physical characteristics (lack of inclusions, grain color), Beckett-Brown et al. (2021) [61] demonstrated that porphyry-derived tourmaline can 
be distinguished from background tourmaline in till (Figure 13B). In a second example, Pisiak et al. (2017) [57] used LA-ICP-MS analysis to distinguish between porphyry-derived and background magnetite grains in glacial sediments down ice of the Mount Polley porphyry $\mathrm{Cu}-\mathrm{Au}-\mathrm{Ag}$ deposit (Figure 14). Other porphyry-related indicator mineral studies have identified discrimination criteria for epidote, zircon [178], and apatite [179,180]. These studies demonstrate that mineral chemistry can be an important exploration tool for porphyry $\mathrm{Cu}$ mineralization in glaciated terrain.
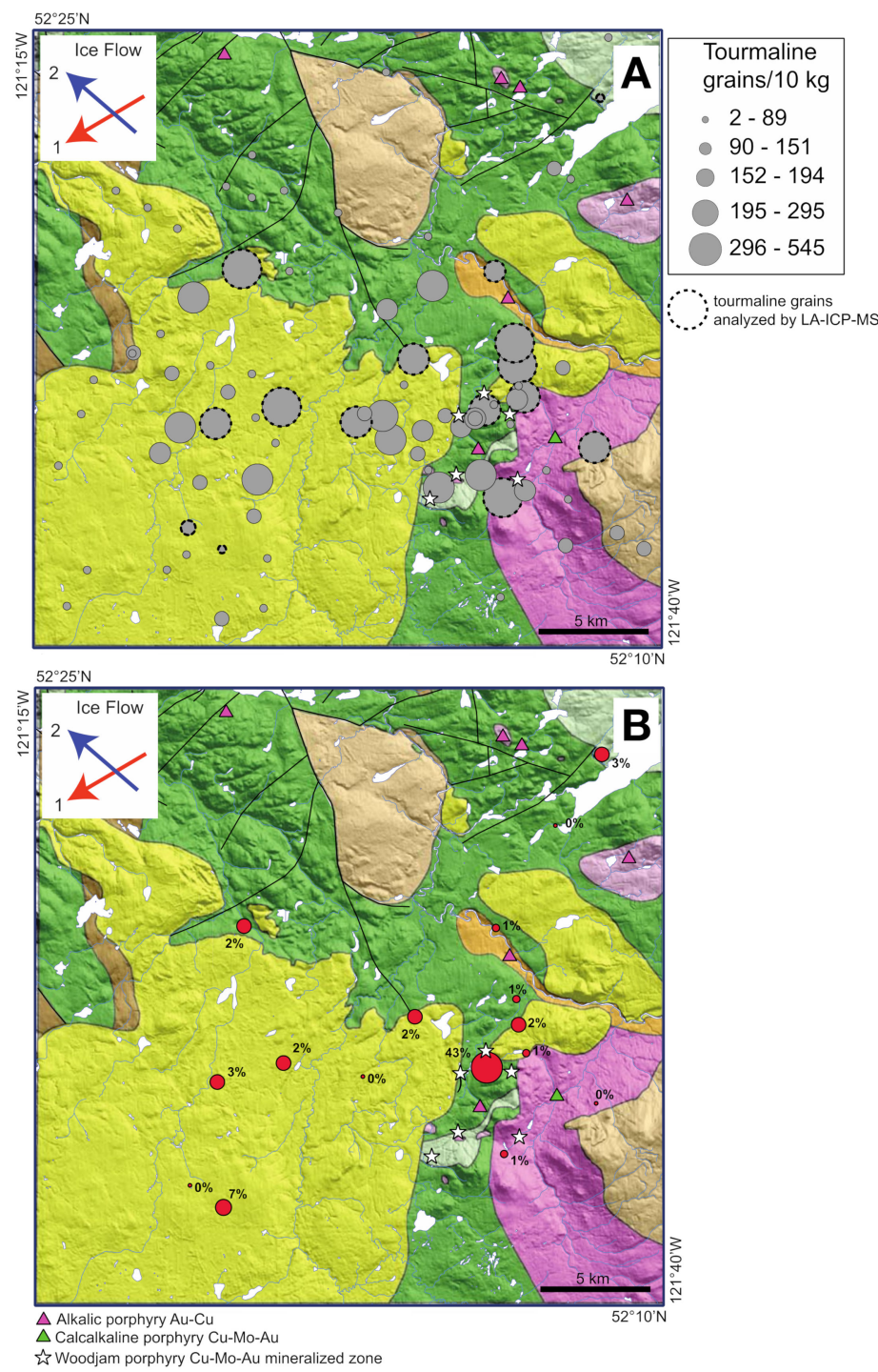

Figure 13. (A) Distribution of $0.25-0.5 \mathrm{~mm}$ tourmaline in the $2.8-3.2$ specific gravity fraction of till samples down ice of the Woodjam porphyry $\mathrm{Cu}$-Au deposits, counts normalized to $10 \mathrm{~kg}$. White dots indicate samples for which the tourmaline grains were analyzed by MLA. (B) Percentage of tourmaline grains that were analyzed and that were identified as 'porphyry-derived' based on high concentrations of $\mathrm{Sr}$, low concentrations of $\mathrm{Zn}$ and $\mathrm{Pb}$, and their lack of inclusions. Bedrock geology from Logan et al. (2010) [181] and Plouffe and Ferbey (2017) [58]. Modified from Beckett-Brown et al. (2021) [61]. 


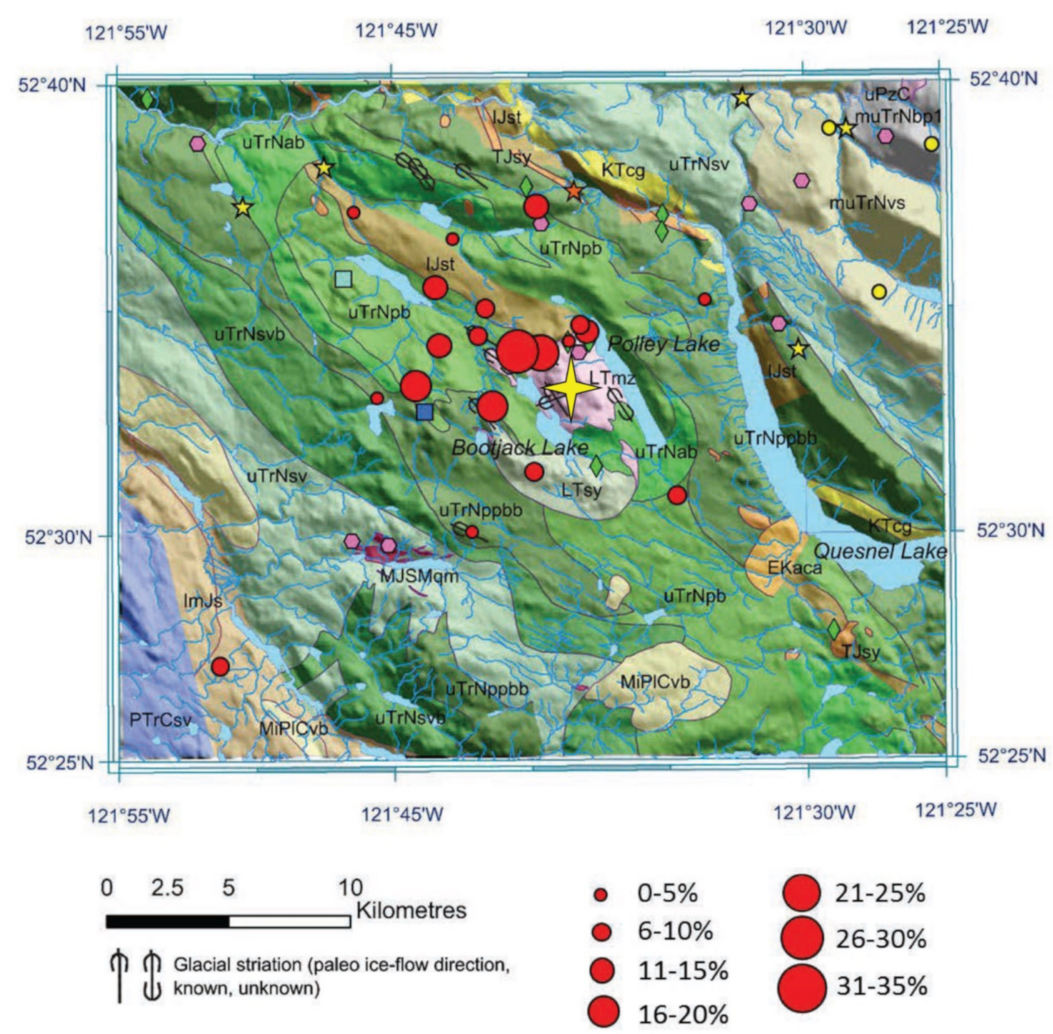

Figure 14. Percentage of magnetite grains that were identified as 'hydrothermal porphyry' based on the Ti-Ni/Cr discrimination diagram of Dare et al. (2014) [118] in 20 till samples around the Mount Polley $\mathrm{Cu}-\mathrm{Au}$ deposit. Symbol size is proportional to percentage of total number of magnetite grain analyzed. Deposit location indicated by yellow star. Bedrock geology from Logan et al. (2010) and Plouffe and Ferbey (2017) [58]. Modified from Pisiak et al. (2017) [57].

\section{Conclusions}

This paper presents an overview of the current methods for, and applications of, indicator mineral chemistry to mineral exploration in the glaciated terrain of Canada. Indicator mineral chemistry can now be used to identify potential bedrock sources of the mineral grains and assess bedrock source fertility and help to prioritize targets for further exploration. There will always be a role for traditional heavy mineral concentrate methods, however automated minerology instrumentation can now augment these methods providing a means to identify more that optically distinct minerals (i.e., $\mathrm{Cr}$ Diopside, $\mathrm{Cr}$ Pyrope, etc.) and provide fertility indexes using mineral chemical of trace elements.

Successful mineral exploration using surficial sediment indicator mineral methods in glaciated terrain requires a high degree of specialization. This type of work requires a person with not only a background in bedrock geology and ore deposits, but also a shift in training to include surficial sample collection and preparation, mineralogy, analytical chemistry, and Quaternary geology. Current exploration models use a team approach, where each individual contributes their own area of expertise and future exploration success will need to incorporate the roles of automated mineralogy and mineral chemistry.

Mineral separation methods are well established for size fractions larger than $0.25 \mathrm{~mm}$, and these methods require a highly qualified mineralogist to visually identify minerals. Indicator mineral identification chemical characterization that utilizes the smaller grain size (i.e., $<0.25 \mathrm{~mm}$ ) and less dense fractions (i.e., $<2.85 \mathrm{~g} / \mathrm{cm}^{3}$ ) of sediments, and methods that incorporate new, faster, and more accessible analytical instruments (i.e., hyperspectral) are becoming more widely available and are currently used in the mineral exploration industry by the combination of SEM, EDS, WDS and LA-ICP-MS methods. Ongoing developments of these methods will decrease the need for extensive specialized mineral identification training, decrease the time and cost of HMC characterization, extend the spatial footprint of 
glacial dispersal trains, and ultimately lead to the identification of new indicator minerals in uncharacterized mineralized systems.

Funding: This research received no external funding.

Data Availability Statement: Not applicable.

Acknowledgments: M.B. McClenaghan's contributions to this paper were supported by the Geological Survey of Canada's Targeted Geoscience Initiative. Natural Resources Canada contribution number: 20210222.

Conflicts of Interest: The authors declare no conflict of interest.

\section{References}

1. Cameron, E.M.; Hamilton, S.M.; Leybourne, M.I.; Hall, G.E.; McClenaghan, M.B. Finding deeply buried deposits using geochemistry. Geochem. Explor. Environ. Anal. 2004, 4, 7-32. [CrossRef]

2. Cohen, D.; Bowell, R. 13.24 - Exploration Geochemistry. In Treatise on Geochemistry, 2nd ed.; Holland, H.D., Turekian, K.K., Eds.; Elsevier: Amsterdam, The Netherlands, 2014; pp. 623-650.

3. Winterburn, P.A.; Noble, R.R.; Lawie, D. Advances in exploration geochemistry, 2007 to 2017 and beyond. Geochem. Explor. Environ. Anal. 2020, 20, 157-166. [CrossRef]

4. McClenaghan, M.B. Indicator mineral methods in mineral exploration. Geochem. Explor. Environ. Anal. 2005, 5, 233-245. [CrossRef]

5. McClenaghan, M.; Paulen, R. Application of till mineralogy and geochemistry to mineral exploration. In Past Glacial Environments; Elsevier: Amsterdam, The Netherlands, 2018; pp. 689-751.

6. McClenaghan, M.; Parkhill, M.; Pronk, A.; Seaman, A.; McCurdy, M.; Leybourne, M. Indicator mineral and geochemical signatures associated with the Sisson W-Mo deposit, New Brunswick, Canada. Geochem. Explor. Environ. Anal. 2017, 17, 297-313. [CrossRef]

7. Poulin, R.S.; Kontak, D.J.; McDonald, A.; McCLenaghan, M.B. Assessing scheelite as an ore-deposit discriminator using its trace-element and REE chemistry. Can. Mineral. 2018, 56, 265-302. [CrossRef]

8. Lindgren, A.; Hugelius, G.; Kuhry, P.; Christensen, T.R.; Vandenberghe, J. Gis-based maps and area estimates of northern hemisphere permafrost extent during the last glacial maximum. Permafr. Periglac. Processes 2016, 27, 6-16. [CrossRef]

9. Fulton, R. Surficial Materials of Canada, Geological Survey of Canada, Map 1880A. J. For. Res. 1995, 34, $267-273$.

10. McClenaghan, M.B.; Spirito, W.A.; Plouffe, A.; McMartin, I.; Campbell, J.E.; Paulen, R.C.; Garrett, R.G.; Hall, G.E.M.; Pelchat, P.; Gauthier, M.S. Geological Survey of Canada Till-Sampling and Analytical Protocols: From Field to Archive; Geological Survey of Canada: Calgary, AB, Canada, 2020; p. 73.

11. Lehtonen, M.; Marmo, J.; Nissinen, A.; Johanson, B.; Pakkanen, L. Glacial dispersal studies using indicator minerals and till geochemistry around two eastern Finland kimberlites. J. Geochem. Explor. 2005, 87, 19-43. [CrossRef]

12. McClenaghan, M.; Kjarsgaard, B. Indicator mineral and geochemical methods for diamond exploration in glaciated terrain in Canada. Geol. Soc. Lond. Spec. Publ. 2001, 185, 83-123. [CrossRef]

13. McClenaghan, M.; Kjarsgaard, B.; Goodfellow, W. Indicator mineral and surficial geochemical exploration methods for kimberlite in glaciated terrain, examples from Canada. Miner. Resour. Can. Synth. Major Depos. Types Dist. Metallog. Evol. Geol. Prov. Explor. Methods Geol. Assoc. Can. Spec. Publ. 2007, 4, 1998.

14. McClenaghan, M.; Ward, B.; Kjarsgaard, I.; Kjarsgaard, B.; Kerr, D.; Dredge, L. Indicator mineral and till geochemical dispersal patterns associated with the Ranch Lake kimberlite, Lac de Gras region, NWT, Canada. Geochemistry: Exploration, Environment, Analysis 2002, 2, 299-319. [CrossRef]

15. McClenaghan, M.; Kjarsgaard, B.; Kjarsgaard, B. Kimberlite indicator mineral chemistry and till geochemistry around the Seed and Triple B kimberlites, Lake Timiskaming, Ontario. Geological Survey of Canada, Open File 2004, 4822.

16. McClenaghan, B.; Kjarsgaard, B.A.; Kjarsgaard, I.M. Kimberlite Indicator Mineral Chemistry of the Bucke and Gravel Kimberlites and Associated Indicator Minerals in Till, Lake Timiskaming, Ontario; Geological Survey of Canada: Calgary, AB, Canada, 2012.

17. Strand, P.; Banas, A.; Baumgartner, M.; Burgess, J.; Paulen, R.; McMartin, I. Tracing kimberlite indicator mineral dispersal trains: An example from the Churchill Diamond Project, Kivalliq region, Nunavut. In Application of Till and Stream Sediment Heavy Mineral and Geochemical Methods to Mineral Exploration in Western and Northern Canada; Paulen, R.C., McMartin, I., Eds.; Short Course Notes; Geological Association of Canada: St. John's, NL, Canada, 2009; Volume 18, pp. 167-175.

18. Stea, R.; Johnson, M.; Hanchar, D.; Paulen, R.; McMartin, I. The geometry of kimberlite indicator mineral dispersal fans in Nunavut, Canada. In Application of Till and Stream Sediment Heavy Mineral and Geochemical Methods to Mineral Exploration in Western and Northern Canada; Paulen, R.C., McMartin, I., Eds.; Short Course Notes; Geological Association of Canada: St. John's, NL, Canada, 2009; Volume 18, pp. 1-13.

19. Pell, J.; Grütter, H.; Neilson, S.; Lockhart, G.; Dempsey, S.; Grenon, H. Exploration and discovery of the Chidliak kimberlite province, Baffin Island, Nunavut: Canada's newest diamond district. In Proceedings of the 10th International Kimberlite Conference, Bangalore, India, 5-11 February 2012; Springer: New Delhi, India, 2013; pp. 209-227. 
20. LaLonde, J.; Bernier, L.; Choiniere, J.; Hébert, C. Dispersion de Gahnite a Partir des Gîte Polymétalliques de Montauban et du Lac Dussault, Comté de Portneuf; Geological Survey of Canada: Calgary, AB, Canada, 1994.

21. Morris, T.F.; Sage, R.P.; Ayer, J.A.; Crabtree, D.C. A study in clinopyroxene composition: Implications for kimberlite exploration Geochem. Explor. Environ. Anal. 2002, 2, 321-331. [CrossRef]

22. Averill, S.A. The application of heavy indicator mineralogy in mineral exploration with emphasis on base metal indicators in glaciated metamorphic and plutonic terrains. Geol. Soc. Lond. Spec. Publ. 2001, 185, 69-81. [CrossRef]

23. Paulen, R.C.; McClenaghan, M.B.; Hicken, A.K. Regional and local ice-flow history in the vicinity of the Izok Lake $\mathrm{Zn}-\mathrm{Cu}-\mathrm{Pb}-\mathrm{Ag}$ deposit, Nunavut. Can. J. Earth Sci. 2013, 50, 1209-1222. [CrossRef]

24. McClenaghan, M.; Paulen, R.; Layton-Matthews, D.; Hicken, A.; Averill, S. Glacial dispersal of gahnite from the Izok Lake Zn-Cu-Pb-Ag VMS deposit, northern Canada. Geochem. Explor. Environ. Anal. 2015, 15, 333-349. [CrossRef]

25. McClenaghan, M.; Peter, J.; Layton-Matthews, D.; Mercier-Langevin, P. Overview of VMS exploration in glaciated terrain using indicator minerals, till geochemistry, and boulder tracing: A Canadian perspective. Target. Geosci. Initiat. 2015, 4, 81-100.

26. Makvandi, S.; Ghasemzadeh-Barvarz, M.; Beaudoin, G.; Grunsky, E.C.; McClenaghan, M.B.; Duchesne, C. Principal component analysis of magnetite composition from volcanogenic massive sulfide deposits: Case studies from the Izok Lake (Nunavut, Canada) and Halfmile Lake (New Brunswick, Canada) deposits. Ore Geol. Rev. 2016, 72, 60-85. [CrossRef]

27. Lougheed, H.D.; McClenaghan, M.B.; Layton-Matthews, D.; Leybourne, M. Exploration Potential of Fine-Fraction Heavy Mineral Concentrates from Till Using Automated Mineralogy: A Case Study from the Izok Lake Cu-Zn-Pb-Ag VMS Deposit, Nunavut, Canada. Minerals 2020, 10, 310. [CrossRef]

28. Paulen, R.; Paradis, S.; Plouffe, A.; Smith, I. Pb and S isotopic composition of indicator minerals in glacial sediments from NW Alberta, Canada: Implications for $\mathrm{Zn}-\mathrm{Pb}$ base metal exploration. Geochem. Explor. Environ. Anal. 2011, 11, 309-320. [CrossRef]

29. Oviatt, N.M.; Gleeson, S.A.; Paulen, R.C.; McClenaghan, M.B.; Paradis, S.; Hanley, J. Characterization and dispersal of indicator minerals associated with the Pine Point Mississippi Valley-type (MVT) district, Northwest Territories, Canada. Can. J. Earth Sci. 2015, 52, 776-794. [CrossRef]

30. Averill, S.; Zimmerman, J. The Riddle Resolved-The Discovery Of The Partridge Gold Zone Using Sonic Drilling In Glacial Overburden At Waddy Lake, Saskatachewan. In CIM Bullettin; Canadian Institute for Mining Metallurgy and Petroleum: Montreal, QC, Canada, 1984; p. 88.

31. Averill, S.; Paulen, R.; McClenaghan, M. Discovery and delineation of the Rainy River gold deposit using glacially dispersed gold grains sampled by deep overburden drilling: A 20 year odyssey. In Proceedings of the New Frontiers for Exploration in Glaciated Terrain workshop, PDAC 2013 International Convention, Toronto, ON, Canada, 1 March 2013; Volume 7374, pp. 37-46.

32. Averill, S.A. Discovery and delineation of the Rainy River gold deposit using glacially dispersed gold grains sampled by deep overburden drilling: A 20 year odyssey. Open File Rep. Geol. Surv. Can. 2017, 37-46. [CrossRef]

33. Plouffe, A. The glacial transport and physical partitioning of mercury and gold in till: Implications for mineral exploration with examples from central British Columbia, Canada. Geol. Soc. Lond. Spec. Publ. 2001, 185, 287-299. [CrossRef]

34. McClenaghan, M.B. Regional local-scale gold grain and till geochemical signatures of lode Au deposits in the western Abitibi greenstone belt, central Canada. Geol. Soc. Spec. Publ. 2001, 185, 201-224. [CrossRef]

35. Sarala, P.; Pulkkinen, E.; Ojala, V.J.; Peltoniemi-Taivalkoski, A. Gold exploration using till at Petäjälehto, northern Finland. Geochem. Explor. Environ. Anal. 2009, 9, 247-255. [CrossRef]

36. McClenaghan, M.B.; Cabri, L.J. Review of gold and platinum group element (PGE) indicator minerals methods for surficial sediment sampling. Geochem. Explor. Environ. Anal. 2011, 11, 251-263. [CrossRef]

37. Sarapää, O.; Sarala, P. Rare earth element and gold exploration in glaciated terrain: Example from the Mäkärä area, northern Finland. Geochem. Explor. Environ. Anal. 2013, 13, 131-143. [CrossRef]

38. Manéglia, N.; Beaudoin, G.; Simard, M. Indicator minerals of the Meliadine orogenic gold deposits, Nunavut (Canada), and application to till surveys. Geochem. Explor. Environ. Anal. 2018, 18, 241-251. [CrossRef]

39. Bajc, A.F.; Hall, G.E. Geochemical Response of Surficial Media, North and East Ranges, Sudbury Basin; Ontario Geological Survey: Sudbury, ON, Canada, 2000.

40. Barnett, P.J.; Averill, S. Heavy mineral dispersal trains in till in the area of the Lac des Iles PGE deposit, northwestern Ontario, Canada. Geochem. Explor. Environ. Anal. 2010, 10, 391-399. [CrossRef]

41. Averill, S. Viable indicator minerals in surficial sediments for two major base metal deposit types: Ni-Cu-PGE and porphyry Cu. Geochem. Explor. Environ. Anal. 2011, 11, 279-291. [CrossRef]

42. McClenaghan, M.; Kjarsgaard, I.; Averill, S.; Layton-Matthews, D.; Crabtree, D.; Matile, G.; McMartin, I.; Pyne, M. Indicator mineral signatures of magmatic Ni-Cu deposits. Thompson Nickel Belt. Manitoba. Part 2-Till data. Geol. Surv. Can. Open File 2013, 7200 .

43. McClenaghan, M.; Ames, D.; Cabri, L. Indicator mineral and till geochemical signatures of the Broken Hammer Cu-Ni-PGE-Au deposit, North Range, Sudbury Structure, Ontario, Canada. Geochem. Explor. Environ. Anal. 2020, 20, 337-356. [CrossRef]

44. Hashmi, S.; Leybourne, M.I.; Layton-Matthews, D.; Hamilton, S.; McClenaghan, M.B.; Voinot, A. Surficial geochemical and mineralogical signatures of Ni-Cu-PGE deposits in glaciated terrain: Examples from the South Range of the Sudbury Igneous Complex, Ontario, Canada. Ore Geology Reviews 2021, 104301. [CrossRef]

45. Makvandi, S.; Pagé, P.; Tremblay, J.; Girard, R. Exploration for Platinum-Group Minerals in Till: A New Approach to the Recovery, Counting, Mineral Identification and Chemical Characterization. Minerals 2021, 11, 264. [CrossRef] 
46. Lehtonen, M.; Lahaye, Y.; O’Brien, H.; Lukkari, S.; Marmo, J.; Sarala, P. Novel technologies for indicator mineral-based exploration. Geol. Surv. Finl. Spec. Pap. 2015, 57, 23-62.

47. Mao, M.; Rukhlov, A.S.; Rowins, S.M.; Spence, J.; Coogan, L.A. Apatite Trace Element Compositions: A Robust New Tool for Mineral Exploration. Econ. Geol. 2016, 111, 1187-1222. [CrossRef]

48. Mackay, D.; Simandl, G.; Ma, W.; Redfearn, M.; Gravel, J. Indicator mineral-based exploration for carbonatites and related specialty metal deposits-A QEMSCAN®orientation survey, British Columbia, Canada. J. Geochem. Explor. 2016, 165, 159-173. [CrossRef]

49. McClenaghan, M.B.; Paulen, R.C.; Kjarsgaard, I.M. Rare metal indicator minerals in bedrock and till at the Strange Lake peralkaline complex, Quebec and Labrador, Canada. Can. J. Earth Sci. Rev. Can. Sci. Terre 2019, 56, 857-869. [CrossRef]

50. Kelley, K.D.; Eppinger, R.G.; Lang, J.; Smith, S.M.; Fey, D.L. Porphyry Cu indicator minerals in till as an exploration tool: Example from the giant Pebble porphyry Cu-Au-Mo deposit, Alaska, USA. Geochem. Explor. Environ. Anal. 2011, 11, 321-334. [CrossRef]

51. Eppinger, R.G.; Fey, D.L.; Giles, S.A.; Grunsky, E.C.; Kelley, K.D.; Minsley, B.J.; Munk, L.; Smith, S.M. Summary of exploration geochemical and mineralogical studies at the giant Pebble porphyry $\mathrm{Cu}$-Au-Mo deposit, Alaska; implications for exploration under cover. Econ. Geol. Bull. Soc. Econ. Geol. 2013, 108, 495-527. [CrossRef]

52. Hashmi, S.; Ward, B.; Plouffe, A.; Leybourne, M.; Ferbey, T. Geochemical and mineralogical dispersal in till from the Mount Polley Cu-Au porphyry deposit, central British Columbia, Canada. Geochem. Explor. Environ. Anal. 2015, 15, 234-249. [CrossRef]

53. Chapman, R.; Allan, M.; Mortensen, J.; Wrighton, T.; Grimshaw, M. A new indicator mineral methodology based on a generic $\mathrm{Bi}-\mathrm{Pb}$-Te-S mineral inclusion signature in detrital gold from porphyry and low/intermediate sulfidation epithermal environments in Yukon Territory, Canada. Miner. Depos. 2018, 53, 815-834. [CrossRef]

54. Chapman, J.B.; Plouffe, A.; Jackson, S.E.; Ryan, J.J.; Ferbey, T. Mineral markers of porphyry processes; regional and local signatures of porphyry prospectivity. Open File Rep. Geol. Surv. Can. 2015, 521-534. [CrossRef]

55. Plouffe, A.; Ferbey, T.; Hashmi, S.; Ward, B.C. Till geochemistry and mineralogy; vectoring towards Cu porphyry deposits in British Columbia, Canada. Geochem. Explor. Environ. Anal. 2016, 16. Pre-Issue Publication. [CrossRef]

56. Plouffe, A.; Kjarsgaard, I.M.; Kobylinski, C.H.; Hattori, K.; Petts, D.C.; Venance, K.E.; Ferbey, T. Discovering the Next Generation of Copper Porphyry Deposits Using Mineral Markers; Open-File Report-Geological Survey of Canada; Natural Resources Canada: Ottawa, ON, Canada, 2019; pp. 321-331. [CrossRef]

57. Pisiak, L.; Canil, D.; Lacourse, T.; Plouffe, A.; Ferbey, T. Magnetite as an indicator mineral in the exploration of porphyry deposits: A case study in till near the Mount Polley Cu-Au deposit, British Columbia, Canada. Econ. Geol. 2017, 112, 919-940. [CrossRef]

58. Plouffe, A.; Ferbey, T. Porphyry Cu indicator minerals in till: A method to discover buried mineralization. Indic. Miner. Till Stream Sediments Can. Cordill. Geol. Assoc. Can. Spec. Pap. 2017, 50, 129-159.

59. McClenaghan, M.B.M.; Beckett-Brown, C.E.; Casselman, S.C. Indicator-Mineral Signatures of the Casino Porphyry Cu-Au-Mo Deposit, Yukon; Geological Survey of Canada: Calgary, AB, Canada, 2020; p. 42.

60. Lee, R.G.; Plouffe, A.; Ferbey, T.; Hart, C.J.; Hollings, P.; Gleeson, S.A. Recognizing porphyry copper potential from till zircon composition: A case study from the Highland Valley Porphyry district, south-central British Columbia. Econ. Geol. 2021, 116, 1035-1045. [CrossRef]

61. Beckett-Brown, C.E.; McDonald, A.; McClenaghan, B.; Plouffe, A.; Ferbey, T. Investigation of Tourmaline Characteristics in Bedrock and Surficial Sediments Samples from Two Canadian Porpryry Copper Systems; Geological Survery of Canada: Ottawa, ON, Canada, 2021; pp. 109-135.

62. Lougheed, H.D.; McClenaghan, M.B.; Layton-Matthews, D.; Leybourne, M.I.; Dobosz, A.N. Automated Indicator Mineral Analysis of Fine-Grained Till Associated with the Sisson W-Mo Deposit, New Brunswick, Canada. Minerals 2021, $11,103$. [CrossRef]

63. McMartin, I.; Corriveau, L.; Beaudoin, G. An orientation study of the heavy mineral signature of the NICO Co-Au-Bi deposit, Great Bear magmatic zone, NW Territories, Canada. Geochem. Explor. Environ. Anal. 2011, 11, 293-307. [CrossRef]

64. Sappin, A.-A.; Dupuis, C.; Beaudoin, G.; Pozza, M.; McMartin, I.; McClenaghan, M. Optimal ferromagnetic fraction in till samples along ice-flow paths: Case studies from the Sue-Dianne and Thompson deposits, Canada. Geochem. Explor. Environ. Anal. 2014, 14, 315-329. [CrossRef]

65. Normandeau, P.; Harlov, D.E.; Corriveau, L.; Paquette, J.; McMartin, I. Characterization of Fluorapatite Within Iron Oxide Alkali-calcic Alteration Systems of the Great Bear Magmatic Zone: A Potential Metasomatic Process Record. Can. Mineral. 2018, 56, 167-187. [CrossRef]

66. Normandeau, P.X. Drift Prospecting Applied to Iron Oxide Alkali-Altered Systems and Iron Oxide Copper-Gold Deposits in the Great Bear Magmatic Zone, Northwest Territories, Canada; McGill University: Montreal, QC, Canada, 2018.

67. Geddes, R.S. The Vixen Lake Indicator Train, Northern Saskatchewan. Ph.D. Thesis, University of Western Ontario, London, ON, Canada, 1980

68. Geddes, R.S. The Vixen Lake indicator train, northern Saskatchewan. In Proceedings of the Prospecting in Areas of Glaciated terrain, 1982: Papers Presented at a Symposium Sponsored by the Geology Division of CIM at the Invitation of the Institution of Mining and Metallurgy, St. John's, NL, Canada, 23-25 August 1982; pp. 264-283.

69. Geddes, R.S. The Vixen Lake indicator train, northern Saskatchewan. CIM Bull. 1974 1982, 75, 58. 
70. Makvandi, S.; Beaudoin, G.; McClenaghan, M.B.; Quirt, D.; Ledru, P. PCA of Fe-oxides MLA data as an advanced tool in provenance discrimination and indicator mineral exploration; case study from bedrock and till from the Kiggavik U deposits area (Nunavut, Canada). J. Geochem. Explor. 2019, 197, 199-211. [CrossRef]

71. Makvandi, S.; Huang, X.; Beaudoin, G.; Quirt, D.; Ledru, P.; Fayek, M. Trace element signatures in hematite and goethite associated with the Kiggavik-Andrew Lake structural trend U deposits (Nunavut, Canada). Miner. Depos. 2021, 56, 509-535. [CrossRef]

72. Makvandi, S.; Beaudoin, G.; McClenaghan, M.B.; Quirt, D. Geochemistry of magnetite and hematite from unmineralized bedrock and local till at the Kiggavik uranium deposit: Implications for sediment provenance. J. Geochem. Explor. 2017, $183,1-21$. [CrossRef]

73. McClenaghan, M.B. Overview of common processing methods for recovery of indicator minerals from sediment and bedrock in mineral exploration. Geochem. Explor. Environ. Anal. 2011, 11, 265-278. [CrossRef]

74. Layton-Matthews, D.; Hamilton, C.; McClenaghan, M. Mineral chemistry: Modern techniques and applications to exploration. In Application of Indicator Mineral Methods to Mineral Exploration; Geological Survey of Canada: Ottawa, ON, Canada, 2014; Volume 7553, pp. 9-18.

75. Wilton, H.; Thompson, G.M.; Grant, D.C. The use of automated indicator mineral analysis in the search for mineralization-a next generation drift prospecting tool. Explor. Newsl. Assoc. Appl. Geochem. Number 2017, 1-28.

76. Jackson, B.; Reid, A.; Wittenberg, J. Rapid production of high quality polished sections for automated image analysis of minerals. Proc. Australas. Inst. Min. Metall. 1984, 93-97.

77. Blaskovich, R.J. Characterizing Waste Rock Using Automated Quantitative Electron Microscopy. Ph.D. Thesis, University of British Columbia, Vancouver, BC, Canada, 2013.

78. Schulz, B.; Sandmann, D.; Gilbricht, S. SEM-based automated mineralogy and its application in geo-and material sciences Minerals 2020, 10, 1004. [CrossRef]

79. Schulz, B.; Merker, G.; Gutzmer, J. Automated SEM mineral liberation analysis (MLA) with generically labelled EDX spectra in the mineral processing of rare earth element ores. Minerals 2019, 9, 527. [CrossRef]

80. Gottlieb, P.; Wilkie, G.; Sutherland, D.; Ho-Tun, E.; Suthers, S.; Perera, K.; Jenkins, B.; Spencer, S.; Butcher, A.; Rayner, J. Using quantitative electron microscopy for process mineralogy applications. JOM 2000, 52, 24-25. [CrossRef]

81. Fandrich, R.; Gu, Y.; Burrows, D.; Moeller, K. Modern SEM-based mineral liberation analysis. Int. J. Miner. Process. 2007, 84, 310-320. [CrossRef]

82. Burrows, D.; Gu, Y. JKMRC mineral liberation analyser-A modern tool for ore characterisation and plant optimisation. Australas. Inst. Min. Metall. Publ. Ser. 2006, 125-139.

83. Gu, Y.; Schouwstra, R.P.; Rule, C. The value of automated mineralogy. Miner. Eng. 2014, 58, 100-103. [CrossRef]

84. Butcher, A.; Helms, T.; Gottlieb, P.; Bateman, R.; Ellis, S.; Johnson, N. Advances in the quantification of gold deportment by QEMSCAN. In Proceedings of the Seventh Mill Operators Conference, Kalgoorlie, WA, Australia, 12-14 October 2000; AusIMM: Melbourne, Australia, 2000.

85. Gottlieb, P.; Butcher, A.; Ho-Tun, E.; Sutherland, D. Applications of automated process mineralogy. In Proceedings of the 6th International Congress on Applied Mineralogy, Gottingen, Germany, 17-19 July 2000.

86. Pirrie, D.; Butcher, A.R.; Power, M.R.; Gottlieb, P.; Miller, G.L. Rapid quantitative mineral and phase analysis using automated scanning electron microscopy (QemSCAN); potential applications in forensic geoscience. Geol. Soc. Lond. Spec. Publ. 2004, 232, 123-136. [CrossRef]

87. Hrstka, T.; Gottlieb, P.; Skala, R.; Breiter, K.; Motl, D. Automated mineralogy and petrology-applications of TESCAN Integrated Mineral Analyzer (TIMA). J. Geosci. 2018, 63, 47-63. [CrossRef]

88. Brough, C.; Strongman, J.; Fletcher, J.; Zajacc, M.; Garside, R.; Garner, C.; Rose, L. Operational mineralogy: An overview of key practices in sample analysis, sample preparation and statistics. In Proceedings of the 15th SGA Biennial Meeting, Glasgow, UK, 27-30 August 2019; pp. 1470-1473.

89. Muto, H.; Shimada, A.; Kaneko, T.; Erdman, N.; Nielsen, C. SEM-EDS Automated Particles Analysis—“INCA Mineral"—Mineral Compositions of Koujaku Granite and Hakkoda Pyroclastic Flow Deposition. In Proceedings of the Microscopy \& Microanalysis 2013 Meeting, Indianapolis, IN, USA, 4-8 August 2013; pp. 53-54.

90. Sylvester, P. Use of the Mineral Liberation Analyzer (MLA) for mineralogical studies of sediments and sedimentary rocks. Mineral Assoc. Can. Short Course Ser. 2012, 42, 1-16.

91. Goodall, W.R.; Scales, P.J.; Butcher, A.R. The use of QEMSCAN and diagnostic leaching in the characterisation of visible gold in complex ores. Miner. Eng. 2005, 18, 877-886. [CrossRef]

92. Hartner, R.; Walters, S.; Berry, R. Optical and SEM-based microscopy integration for optimisation of geometallurgical modelling and ore deposit characterisation. In Proceedings of the 1st International Geometallurgy Conference (GeoMet 2011), Carlton, Australia, 5-11 September 2011; pp. 157-162.

93. Newbury, D.E.; Ritchie, N.W.M. Performing elemental microanalysis with high accuracy and high precision by scanning electron microscopy/silicon drift detector energy-dispersive X-ray spectrometry (SEM/SDD-EDS). J. Mater. Sci. 2015, 50, 493-518. [CrossRef]

94. Laigo, J.; Christien, F.; Le Gall, R.; Tancret, F.; Furtado, J. SEM, EDS, EPMA-WDS and EBSD characterization of carbides in HP type heat resistant alloys. Mater. Charact. 2008, 59, 1580-1586. [CrossRef] 
95. Herrington, C.R. Quantitative EDS and WDS X-ray microanalysis of semiconductor materials: Principles and comparisons. J. Electron Microsc. Tech. 1985, 2, 471-479. [CrossRef]

96. Kimura, T.; Nishida, K.; Tanuma, S. Spatial resolution of a wavelength-dispersive electron probe microanalyzer equipped with a thermal field emission gun. Microchim. Acta 2006, 155, 175-178. [CrossRef]

97. Hombourger, C.; Outrequin, M. Quantitative analysis and high-resolution X-ray mapping with a field emission electron microprobe. Microsc. Today 2013, 21, 10-15. [CrossRef]

98. Nikonow, W.; Rammlmair, D.; Meima, J.A.; Schodlok, M.C. Advanced mineral characterization and petrographic analysis by $\mu$-EDXRF, LIBS, HSI and hyperspectral data merging. Mineral. Petrol. 2019, 113, 417-431. [CrossRef]

99. Figueroa, R.; Lozano, E.; Belmar, F.; Alcaman, D.; Von Bohlen, A.; Oliveira, C.; Silva, A.; Veloso, J. Characteristics of a robust and portable large area X-ray fluorescence imaging system. X-Ray Spectrom. 2014, 43, 126-130. [CrossRef]

100. Flude, S.; Haschke, M.; Storey, M. Application of benchtop micro-XRF to geological materials. Mineral. Mag. 2017, 81, 923-948. [CrossRef]

101. Manceau, A.; Marcus, M.A.; Tamura, N. Quantitative speciation of heavy metals in soils and sediments by synchrotron X-ray techniques. Rev. Mineral. Geochem. 2002, 49, 341-428. [CrossRef]

102. Sanchez-Valle, C.; Martinez, I.; Daniel, I.; Philippot, P.; Bohic, S.; Simionovici, A. Dissolution of strontianite at high PT conditions: An in-situ synchrotron X-ray fluorescence study. Am. Mineral. 2003, 88, 978-985. [CrossRef]

103. Schmidt, C.; Rickers, K.; Bilderback, D.H.; Huang, R. In situ synchrotron-radiation XRF study of REE phosphate dissolution in aqueous fluids to $800 \mathrm{C}$. Lithos 2007, 95, 87-102. [CrossRef]

104. Friedrich, S.; Niedermayr, T.; Drury, O.; Cunningham, M.F.; Van den Berg, M.; Ullom, J.; Loshak, A.; Funk, T.; Cramer, S.; Batteux, J. A superconducting detector endstation for high-resolution energy-dispersive SR-XRF. Nucl. Instrum. Methods Phys. Res. Sect. A Accel. Spectrometers Detect. Assoc. Equip. 2001, 467, 1117-1120. [CrossRef]

105. Geil, E.; Thorne, R. Correcting for surface topography in X-ray fluorescence imaging. J. Synchrotron Radiat. 2014, 21, 1358-1363. [CrossRef] [PubMed]

106. Haschke, M.; Haller, M. Examination of poly-capillary lenses for their use in micro-XRF spectrometers. X-Ray Spectrom. Int. J. 2003, 32, 239-247. [CrossRef]

107. Guilherme, A.; Buzanich, G.; Carvalho, M. Focusing systems for the generation of X-ray micro beam: An overview. Spectrochim. Acta Part B At. Spectrosc. 2012, 77, 1-8. [CrossRef]

108. Bruker. Nano GmbH, G. M4 TORNADO AMICS Brochure. Available online: https://mbna.bruker.com/acton/formfd/15240/02 22:d-0002 (accessed on 23 March 2021).

109. Jiao, Y.; Qiu, K.-H.; Zhang, P.-C.; Li, J.-F.; Zhang, W.-T.; Chen, X.-F. Process mineralogy of Dalucao rare earth ore and design of beneficiation process based on AMICS. Rare Met. 2020, 39, 959-966. [CrossRef]

110. Zhou, J.; Gu, Y. Geometallurgical characterization and automated mineralogy of gold ores. In Gold Ore Processing; Elsevier: Amsterdam, The Netherlands, 2016; pp. 95-111.

111. Sherman, J. The theoretical derivation of fluorescent X-ray intensities from mixtures. Spectrochim. Acta 1955, 7, 283-306. [CrossRef]

112. Rousseau, R.M. Fundamental algorithm between concentration and intensity in XRF analysis 1-Theory. X-Ray Spectrom. 1984, 13, 115-120. [CrossRef]

113. Rousseau, R.M. Fundamental algorithm between concentration and intensity in XRF analysis 2-Practical application. X-Ray Spectrom. 1984, 13, 121-125. [CrossRef]

114. Van Sprang, H.A. Fundamental parameter methods in XRF spectroscopy. Adv. X-Ray Anal. 2000, 42, 1-10.

115. Lawie, D. Exploratory Data Analysis For Target Generation. In Proceedings of the AIG 'Geo-Computing 2010, Brisbane, Australia, 29 September-1 October 2010; pp. 77-80.

116. Hale, M.; Thompson, M.; Wheatley, M. Laser ablation of stream-sediment pebble coatings for simultaneous multi-element analysis in geochemical exploration. J. Geochem. Explor. 1984, 21, 361-371. [CrossRef]

117. Jackson, S.E.; Longerich, H.P.; Dunning, G.R.; Freyer, B.J. The application of laser-ablation microprobe; inductively coupled plasma-mass spectrometry (LAM-ICP-MS) to in situ trace-element determinations in minerals. Can. Mineral. 1992, 30, 1049-1064.

118. Dare, S.A.; Barnes, S.-J.; Beaudoin, G.; Méric, J.; Boutroy, E.; Potvin-Doucet, C. Trace elements in magnetite as petrogenetic indicators. Miner. Depos. 2014, 49, 785-796. [CrossRef]

119. Duran, C.J.; Barnes, S.-J.; Corkery, J.T. Trace element distribution in primary sulfides and Fe-Ti oxides from the sulfide-rich pods of the Lac des Iles Pd deposits, Western Ontario, Canada: Constraints on processes controlling the composition of the ore and the use of pentlandite compositions in exploration. J. Geochem. Explor. 2016, 166, 45-63.

120. Duran, C.J.; Dubé-Loubert, H.; Pagé, P.; Barnes, S.-J.; Roy, M.; Savard, D.; Cave, B.J.; Arguin, J.-P.; Mansur, E.T. Applications of trace element chemistry of pyrite and chalcopyrite in glacial sediments to mineral exploration targeting: Example from the Churchill Province, northern Quebec, Canada. J. Geochem. Explor. 2019, 196, 105-130. [CrossRef]

121. Cook, N.; Ciobanu, C.L.; George, L.; Zhu, Z.-Y.; Wade, B.; Ehrig, K. Trace element analysis of minerals in magmatic-hydrothermal ores by laser ablation inductively-coupled plasma mass spectrometry: Approaches and opportunities. Minerals 2016, 6, 111. [CrossRef]

122. Reich, M.; Large, R.; Deditius, A.P. New advances in trace element geochemistry of ore minerals and accessory phases. Ore Geol. Rev. 2017, 81, 1215-1217. [CrossRef] 
123. Cooke, D.R.; Agnew, P.; Hollings, P.; Baker, M.; Chang, Z.; Wilkinson, J.J.; White, N.C.; Zhang, L.; Thompson, J.; Gemmell, J. Porphyry indicator minerals (PIMS) and porphyry vectoring and fertility tools (PVFTS)-indicators of mineralization styles and recorders of hypogene geochemical dispersion halos. In Proceedings of the Sixth Decennial International Conference on Mineral Exploration, Toronto, ON, Canada, 22-25 October 2017.

124. Del Real, I.; Smieska, L.; Thompson, J.; Martinez, C.; Thomas, J.; Layton-Matthews, D. Using multiple micro-analytical techniques for evaluating quantitative synchrotron-XRF elemental mapping of hydrothermal pyrite. J. Anal. At. Spectrom. 2019, 34, 1724-1738. [CrossRef]

125. Kadel-Harder, I.M.; Spry, P.G.; Layton-Matthews, D.; Voinot, A.; von der Handt, A.; McCombs, A.L. Paragenetic relationships between low and high-grade gold mineralization in the Cripple Creek Au-Te deposit, Colorado: Trace element studies of pyrite. Ore Geol. Rev. 2020, 127, 103847. [CrossRef]

126. Schmidt, M.A.; Leybourne, M.I.; Peter, J.M.; Petts, D.C.; Jackson, S.E.; Layton-Matthews, D. Development of a laser ablation ICP-MS method for the analysis of fluid inclusions associated with volcanogenic massive sulfide deposits. Geochem. Explor. Environ. Anal. 2021, 21, geochem2020-043. [CrossRef]

127. Godefroy-Rodríguez, M.; Hagemann, S.; Frenzel, M.; Evans, N.J. Laser ablation ICP-MS trace element systematics of hydrothermal pyrite in gold deposits of the Kalgoorlie district, Western Australia. Miner. Depos. 2020, 55, 823-844. [CrossRef]

128. Alexandre, P.; Kyser, K.; Layton-Matthews, D.; Joy, B.; Uvarova, Y. Chemical compositions of natural uraninite. Can. Mineral. 2015, 53, 595-622. [CrossRef]

129. Gadd, M.G.; Layton-Matthews, D.; Peter, J.M. Non-hydrothermal origin of apatite in SEDEX mineralization and host rocks of the Howard's Pass district, Yukon, Canada. Am. Mineral. 2016, 101, 1061-1071. [CrossRef]

130. Hill, S.J. Inductively Coupled Plasma Spectrometry and Its Applications; John Wiley \& Sons: Hoboken, NJ, USA, 2008 ; Volume 8.

131. Arevalo, R., Jr.; Bellucci, J.; McDonough, W.F. GGR Biennial Review: Advances in Laser Ablation and Solution ICP-MS from 2008 to 2009 with Particular Emphasis on Sensitivity Enhancements, Mitigation of Fractionation Effects and Exploration of New Applications. Geostand. Geoanal. Res. 2010, 34, 327-341. [CrossRef]

132. Rogers, R.R.; Fricke, H.C.; Addona, V.; Canavan, R.R.; Dwyer, C.N.; Harwood, C.L.; Koenig, A.E.; Murray, R.; Thole, J.T.; Williams, J. Using laser ablation-inductively coupled plasma-mass spectrometry (LA-ICP-MS) to explore geochemical taphonomy of vertebrate fossils in the Upper Cretaceous Two Medicine and Judith River formations of Montana. Palaios 2010, 25, 183-195. [CrossRef]

133. Koch, J.; Günther, D. Review of the state-of-the-art of laser ablation inductively coupled plasma mass spectrometry. Appl. Spectrosc. 2011, 65, 155A-162A. [CrossRef] [PubMed]

134. Motelica-Heino, M.; Donard, O.F.X. Comparison of UV and IR Laser Ablation ICP-MS on Silicate Reference Materials and Implementation of Normalisation Factors for Quantitative Measurements. Geostand. Newsl. 2001, 25, 345-359. [CrossRef]

135. Guillong, M.; Hametner, K.; Reusser, E.; Wilson, S.A.; Günther, D. Preliminary characterisation of new glass reference materials (GSA-1G, GSC-1G, GSD-1G and GSE-1G) by laser ablation-inductively coupled plasma-mass spectrometry using $193 \mathrm{~nm}, 213 \mathrm{~nm}$ and $266 \mathrm{~nm}$ wavelengths. Geostand. Geoanal. Res. 2005, 29, 315-331. [CrossRef]

136. Jochum, K.; Stoll, B.; Herwig, K.; Willbold, M. Validation of LA-ICP-MS trace element analysis of geological glasses using a new solid-state $193 \mathrm{~nm}$ Nd: YAG laser and matrix-matched calibration. J. Anal. At. Spectrom. 2007, 22, 112-121. [CrossRef]

137. Gaboardi, M.; Humayun, M. Elemental fractionation during LA-ICP-MS analysis of silicate glasses: Implications for matrixindependent standardization. J. Anal. At. Spectrom. 2009, 24, 1188-1197. [CrossRef]

138. Poitrasson, F.; Mao, X.; Mao, S.S.; Freydier, R.; Russo, R.E. Comparison of ultraviolet femtosecond and nanosecond laser ablation inductively coupled plasma mass spectrometry analysis in glass, monazite, and zircon. Anal. Chem. 2003, 75, 6184-6190. [CrossRef] [PubMed]

139. Horn, I. Comparison of femtosecond and nanosecond laser interactions with geological matrices and their influence on accuracy and precision of LA-ICP-MS data. Mineral. Assoc. Can. Short Course 2008, 40, 53-65.

140. Gonzalez, J.J.; Liu, C.; Wen, S.-B.; Mao, X.; Russo, R.E. Metal particles produced by laser ablation for ICP-MS measurements. Talanta 2007, 73, 567-576. [CrossRef]

141. Saetveit, N.J.; Bajic, S.J.; Baldwin, D.P.; Houk, R. Influence of particle size on fractionation with nanosecond and femtosecond laser ablation in brass by online differential mobility analysis and inductively coupled plasma mass spectrometry. J. Anal. At. Spectrom. 2008, 23, 54-61. [CrossRef]

142. Glaus, R.; Kaegi, R.; Krumeich, F.; Günther, D. Phenomenological studies on structure and elemental composition of nanosecond and femtosecond laser-generated aerosols with implications on laser ablation inductively coupled plasma mass spectrometry. Spectrochim. Acta Part B At. Spectrosc. 2010, 65, 812-822. [CrossRef]

143. Günther, D.; Heinrich, C.A. Comparison of the ablation behaviour of $266 \mathrm{~nm} \mathrm{Nd:} \mathrm{YAG} \mathrm{and} 193 \mathrm{~nm}$ ArF excimer lasers for LA-ICP-MS analysis. J. Anal. At. Spectrom. 1999, 14, 1369-1374. [CrossRef]

144. Günther, D.; Horn, I.; Hattendorf, B. Recent trends and developments in laser ablation-ICP-mass spectrometry. Fresenius J. Anal. Chem. 2000, 368, 4-14. [CrossRef] [PubMed]

145. Hirata, T.; Asada, Y.-I.; Apinya, T.; Ohno, T.; Iizuka, T.; Hayano, Y.; Tanimizu, M.; Orihashi, Y. Improvements in the precision and accuracy of elemental and isotopic analyses of geochemical samples by a laser ablation-ICP-mass spectrometer. Bunseki Kagaku 2004, 53, 491-501. [CrossRef] 
146. Bussweiler, Y.; Borovinskaya, O.; Tanner, M. Laser Ablation and inductively coupled plasma-time-of-flight mass spectrometry-A powerful combination for high-speed multielemental imaging on the micrometer scale. Spectroscopy 2017, 32, 14-20.

147. Burger, M.; Schwarz, G.; Gundlach-Graham, A.; Käser, D.; Hattendorf, B.; Günther, D. Capabilities of laser ablation inductively coupled plasma time-of-flight mass spectrometry. J. Anal. At. Spectrom. 2017, 32, 1946-1959. [CrossRef]

148. Guilhaus, M.; Selby, D.; Mlynski, V. Orthogonal acceleration time-of-flight mass spectrometry. Mass Spectrom. Rev. 2000, 19, 65-107. [CrossRef]

149. Gundlach-Graham, A.; Burger, M.; Allner, S.; Schwarz, G.; Wang, H.A.O.; Gyr, L.; Grolimund, D.; Hattendorf, B.; Günther, D High-Speed, High-Resolution, Multielemental Laser Ablation-Inductively Coupled Plasma-Time-of-Flight Mass Spectrometry Imaging: Part I. Instrumentation and Two-Dimensional Imaging of Geological Samples. Anal. Chem. 2015, 87, 8250-8258. [CrossRef] [PubMed]

150. Willard, H.; Merritt, L., Jr.; Dean, J.; Settle, F., Jr. Instrumental Methods of Analysis; Wadsworth Publishing Co.: Belmont, CA, USA, 1988.

151. Usman, A.; Ander, E.L.; Bailey, E.H.; Nelms, S.; Pashley, V.; Young, S.D.; Chenery, S.R. Optimisation of a current generation ICP-QMS and benchmarking against MC-ICP-MS spectrometry for the determination of lead isotope ratios in environmental samples. J. Anal. At. Spectrom. 2018, 33, 2184-2194. [CrossRef]

152. Gießmann, U.; Greb, U. High resolution ICP-MS-A new concept for elemental mass spectrometry. Fresenius J. Anal. Chem. 1994, 350, 186-193. [CrossRef]

153. Jakubowski, N.; Moens, L.; Vanhaecke, F. Sector field mass spectrometers in ICP-MS. Spectrochim. Acta Part B At. Spectrosc. 1998, 53, 1739-1763. [CrossRef]

154. Roberts, N.M.; Drost, K.; Horstwood, M.S.; Condon, D.J.; Chew, D.; Drake, H.; Milodowski, A.E.; McLean, N.M.; Smye, A.J.; Walker, R.J. Laser ablation inductively coupled plasma mass spectrometry (LA-ICP-MS) U-Pb carbonate geochronology: Strategies, progress, and limitations. Geochronology 2020, 2, 33-61. [CrossRef]

155. Miliszkiewicz, N.; Walas, S.; Tobiasz, A. Current approaches to calibration of LA-ICP-MS analysis. J. Anal. At. Spectrom. 2015, 30, 327-338. [CrossRef]

156. Lin, J.; Liu, Y.; Yang, Y.; Hu, Z. Calibration and correction of LA-ICP-MS and LA-MC-ICP-MS analyses for element contents and isotopic ratios. Solid Earth Sci. 2016, 1, 5-27. [CrossRef]

157. Arevalo, R., Jr.; McDonough, W.F.; Piccoli, P.M. In situ determination of first-row transition metal, Ga and Ge abundances in geological materials via medium-resolution LA-ICP-MS. Geostand. Geoanal. Res. 2011, 35, 253-273. [CrossRef]

158. Bertini, M.; Izmer, A.; Vanhaecke, F.; Krupp, E.M. Critical evaluation of quantitative methods for the multi-elemental analysis of ancient glasses using laser ablation inductively coupled plasma mass spectrometry. J. Anal. At. Spectrom. 2013, 28, 77-91. [CrossRef]

159. Jochum, K.P.; Dingwell, D.B.; Rocholl, A.; Stoll, B.; Hofmann, A.W.; Becker, S.; Besmehn, A.; Bessette, D.; Dietze, H.J.; Dulski, P. The preparation and preliminary characterisation of eight geological MPI-DING reference glasses for in-situ microanalysis. Geostand. Newsl. 2000, 24, 87-133. [CrossRef]

160. Jochum, K.P.; Nohl, U. Reference materials in geochemistry and environmental research and the GeoReM database. Chem. Geol. 2008, 253, 50-53. [CrossRef]

161. Jochum, K.P.; Nohl, U.; Rothbarth, N.; Schwager, B.; Stoll, B.; Weis, U. Geostandards and Geoanalytical Research bibliographic review 2011. Geostand. Geoanal. Res. 2012, 36, 415-419. [CrossRef]

162. Jochum, K.P.; Stoll, B.; Herwig, K.; Willbold, M.; Hofmann, A.W.; Amini, M.; Aarburg, S.; Abouchami, W.; Hellebrand, E.; Mocek, B. MPI-DING reference glasses for in situ microanalysis: New reference values for element concentrations and isotope ratios. Geochem. Geophys. Geosyst. 2006, 7. [CrossRef]

163. Jochum, K.P.; Willbold, M.; Raczek, I.; Stoll, B.; Herwig, K. Chemical Characterisation of the USGS Reference Glasses GSA-1G, GSC-1G, GSD-1G, GSE-1G, BCR-2G, BHVO-2G and BIR-1G Using EPMA, ID-TIMS, ID-ICP-MS and LA-ICP-MS. Geostand. Geoanal. Res. 2005, 29, 285-302. [CrossRef]

164. Kaiyun, C.; Honglin, Y.; Zhian, B.; Chunlei, Z.; Mengning, D. Precise and accurate in situ determination of lead isotope ratios in NIST, USGS, MPI-DING and CGSG glass reference materials using femtosecond laser ablation MC-ICP-MS. Geostand. Geoanal. Res. 2014, 38, 5-21. [CrossRef]

165. Hicken, A. Glacial Dispersal of Indicator Minerals from the Izok Lake Zn-Cu-Pb-Ag VMS Deposit, Nunavut, Canada. Ph.D. Thesis, Queen's University, Kingston, ON, Canada, 2012.

166. Hicken, A.; McClenaghan, M.; Paulen, R.; Layton-Matthews, D. Till Geochemical Signature of the Izok Lake Zn-Cu-Pb-Ag VMS Deposit, Nunavut. Geol. Surv. Can. Open File 2012, 7046, 114.

167. Morrison, I.R. Geology of the Izok massive sulfide deposit, Nunavut Territory, Canada. Explor. Min. Geol. 2004, 13, 25-36. [CrossRef]

168. Mortensen, J.; Thorpe, R.; Padgham, W.; King, J.; Davis, W. U-Pb zircon ages for felsic volcanism in the Slave Province, NWT. Radiogenic Age Isot. Stud. Rep. 1988, 2, 88-92.

169. Stacey, J.t.; Kramers, J. Approximation of terrestrial lead isotope evolution by a two-stage model. Earth Planet. Sci. Lett. 1975, 26, 207-221. [CrossRef]

170. Van Staal, C. Geology and tectonic history of the Bathurst Supergroup, Bathurst Mining Camp, and its relationships to coeval rocks in southeastern New Brunswick and adjacent Maine-a synthesis. Econ. Geol. Mon. 2003, 11, 37-60. 
171. McClenaghan, M.B.; Kjarsgaard, I.M.; Layton-Matthews, D.; Griffin, W.L. CAMIRO Project 04E01: Chemistry of Resistate to Moderately Resitate Indicator Minerals for Ni-Cu-PGE Deposits: Report 3 Mineral Chemistry Data for Cr-Diopside, Chromite and Olivine from the Thompson Nickel Belt; CAMIRO: Toronto, ON, Canada, 2009.

172. Zwanzig, H.; Macek, J.; McGregor, C. Lithostratigraphy and geochemistry of the high-grade metasedimentary rocks in the Thompson Nickel Belt and adjacent Kisseynew Domain, Manitoba: Implications for nickel exploration. Econ. Geol. 2007, 102, 1197-1216. [CrossRef]

173. Layton-Matthews, D.; Lesher, C.M.; Burnham, O.M.; Liwanag, J.; Halden, N.M.; Hulbert, L.; Peck, D.C.; Goodfellow, W. Magmatic Ni-Cu-platinum-group element deposits of the Thompson Nickel Belt. Geol. Assoc. Can. Miner. Depos. Div. 2007, 409-432.

174. Bleeker, W. New structural-metamorphic constraints on Early Proterozoic oblique collision along the Thompson Nickel Belt, Manitoba, Canada. In The Early Proterozoic Trans-Hudson Orogen of North America; Geological Association of Canada: St. John's, NL, Canada, 1990; Special Paper 37; pp. 57-73.

175. Mao, M.; Rukhlov, A.; Rowins, S.; Hickin, A.; Ferbey, T.; Bustard, A.; Spence, J.; Coogan, L. A novel approach using detrital apatite and till geochemistry to identify covered mineralization in the TREK area of the Nechako Plateau, British Columbia. Indic. Miner. Till Stream Sediments Can. Cordill. Geol. Assoc. Can. Spec. Pap. 2017, 50, 191-243.

176. Celis, A. Titanite as an Indicator Mineral for Alkalic Cu-Au Porphyry Deposits in South Central British Columbia. Ph.D. Thesis, University of British Columbia, Vancouver, BC, Canada, 2015.

177. Plouffe, A.; Ferbey, T. Indicator-Mineral Content of Bedrock and Till at the Gibraltar Porphyry Cu-Mo Deposit and the Woodjam Porphyry $\mathrm{Cu}$-Au-Mo Prospect, South-Central British Columbia; Geological Survey of Canada: Ottawa, ON, Canada, 2019.

178. Kobylinski, C.; Hattori, K.; Smith, S.; Plouffe, A. High Cerium Anomalies in Zircon from Intrusions Associated with Porphyry Copper Mineralization in the Gibraltar Deposit, South-Central British Columbia; Open File 8430; Geological Survey of Canada: Ottawa, ON, Canada, 2018.

179. Rukhlov, A.S.; Plouffe, A.; Ferbey, T.; Mao, M.; Spence, J. Application of trace-element compositions of detrital apatite to explore for porphyry deposits in central British Columbia. In Geological Fieldwork; British Columbia Ministry of Energy and Mines, British Columbia Geological Survey: Victoria, BC, Canada, 2016; pp. 145-179.

180. Bouzari, F.; Hart, C.J.; Bissig, T.; Barker, S. Hydrothermal alteration revealed by apatite luminescence and chemistry: A potential indicator mineral for exploring covered porphyry copper deposits. Econ. Geol. 2016, 111, 1397-1410. [CrossRef]

181. Logan, J.; Schiarizza, P.; Struik, L.; Barnett, C.; Nelson, J.; Kowalczyk, P.; Ferri, F.; Mihalynuk, M.; Thomas, M.; Gammon, P. Bedrock Geology of the QUEST Map Area, Central British Columbia. British Columbia Ministry of Energy and Mines, British Columbia Geological Survey: Victoria, BC, Canada, 2010; Geoscience BC Report; Volume 5. 